\title{
FEATURES OF UNDERGROWTH DEVELOPMENT IN EASTERN EUROPEAN FORESTS
}

\section{O. I. Evstigneev}

State Nature Biosphere Reserve "Bryanskii Les", Nerussa Station, Bryansk Oblast, 242180, Russia E-mail: quercus_eo@mail.ru

\section{N. V. Korotkova}

Moscow State Pedagogical University, 1/1 Malaya Pirogovskaya street, Moscow, 119991, Russia

E-mail: natalya-1998-494@mail.ru

\section{ОСОБЕННОСТИ РАЗВИТИЯ ПОДРОСТА АЕРЕВЬЕВ В ВОСТОЧНОЕВРОПЕЙСКИХ ЛЕСАХ}

\section{О. И. Евстигнеев}

Государственный природный биосферный заповедник «Брянский лес», Россия, 242180, Брянская область, ст. Нерусса E-mail:quercus_eo@mail.ru

\section{Н. В. Короткова}

Московский педагогический государственный университет, Россия, 119991, г. Москва, ул. Малая Пироговская, 1/1 E-mail: natalya-1998-494@mail.ru

Abstract. We studied the development of 13 tree species growing in the undergrowth of hornbeam forests in the Kanev Reserve in Cherkasy Oblast (Ukraine) and spruce-broadleaved and pine forests in the Bryansk Forest Reserve (Russia). We analysed the following biological features of these species in limited light conditions: age, average annual increase in biomass (production), growth patterns of the aboveground axis, crown area, specific density of the leaf area and the ability to change to a quasi-senile state. Analysis of these biological properties allowed us to distinguish two large groups of species, which are characterized by a set of interrelated features. The first group included Betula pendula, Pinus sylvestris, Populus tremula, Quercus robur and Salix caprea. For these species, low shade tolerance is combined with rapid development, high intensity in growth and physiological processes (photosynthesis and respiration), with large average annual biomass increase and short lifespan when growing in the undergrowth due to a lack of light. This set of features allows the trees to occupy habitats with good light conditions, which are found in large-sized treefall gaps as well as sparse forests. The second group included Acer campestre, A. platanoides, A. tataricum, Carpinus betulus, Fraxinus excelsior, Picea abies, Tilia cordata and Ulmus glabra. For these species, high shade tolerance is combined with slow growth rates, with a low intensity of growth and physiological processes, with small average annual biomass increase and long-term existence of individuals in limited light conditions. Species with this complex of features are adapted to habitats beneath a dark forest canopy formed by spruce and broadleaved trees with crowns that cast deep shadow. These large species groups appear in the vegetation cover as complementary formations and form contrasting communities. Tree species within each group determine the resilience of forest communities as they are able to replace each other in the event of a reduction in the number of individuals of any species. The basis of this ability is the congeniality of species according to their light requirements and biological properties.

Keywords: East European forests, tree ontogeny, biological age of plants, light minimum for undergrowth, shade tolerance of undergrowth, scales of shade tolerance, undergrowth productivity, age of undergrowth.

For citation: Evstigneev O.I., Korotkova N.V. Features of undergrowth development in eastern european forests. Russian Journal of Ecosystem Ecology. 2019;4(2). Available from: https://doi.org/10.21685/2500-0578-2019-2-3

Аннотация. Изучено развитие подроста 13 видов деревьев в грабовых лесах Каневского заповедника Черкасской области (Украина), а также в елово-широколиственных и сосновых лесах заповедника «Брянский лес» (Россия). Проанализированы биологические особенности подроста, который сформировался при световом минимуме: его возраст, среднегодовой прирост биомассы (продуктивность), характер роста надземной оси, площадь кроны, удельная плотность листьев, способность переходить в квазисенильное состояние и др. Анализ этих биологических свойств подроста при световом минимуме позволил выделить две крупные группы видов, которые отличаются совокупностью взаимосвязанных признаков. К первой группе относятся Betula pendula, Pinus sylvestris, Populus tremula, Quercus robur и Salix caprea. У этих видов малая теневыносливость сочетается с быстрыми темпами развития, с высокой интенсивностью ростовых и физиологических 
процессов (фотосинтеза и дыхания), с большой продуктивностью и короткой жизнью подроста при световом голоде. Этот комплекс признаков позволяет деревьям осваивать светлые местообитания, которые представлены окнами больших размеров на месте вывалов нескольких деревьев, а также разреженными лесами паркового типа. Ко второй группе принадлежат Acer campestre, A. platanoides, A. tataricum, Carpinus betulus, Fraxinus excelsior, Picea abies, Tilia cordata и Ulmus glabra. У этих видов высокая теневыносливость совмещается с медленными темпами развития, с низкой интенсивностью ростовых и физиологических процессов, с малой продуктивностью и длительным существованием особей при ограниченной освещенности. Виды с этим комплексом признаков приспособлены к освоению окон небольших размеров, а также способны приживаться под темным пологом леса, который формируют ель и широколиственные деревья с тенистой кроной. Эти две крупные группы видов выступают в растительном покрове как комплементарные образования. Они формируют контрастные сообщества. Виды деревьев внутри каждой группы определяют устойчивость лесных сообществ, поскольку способны заменять друг друга в случае сокращения численности особей какого-либо вида. В основе этой способности лежит близость видов по световым потребностям и биологическим свойствам.

Ключевые слова: Восточноевропейские леса, онтогенез дерева, биологический возраст растений, световой минимум подроста, теневыносливость подроста, шкалы теневыносливости, продуктивность подроста, возраст подроста.

\section{Introduction}

Modern communities have been radically transformed by human beings. In this context, the most important problem in forest ecology is to reconstruct the structure of undisturbed (climax) communities. It is known that light is the leading formative factor in forest cenoses [1]. A detailed study of tree development under different light conditions could underlie this reconstruction. Previous studies have shown that the most efficient approach to the study of tree ontogenesis is to use the concepts of the biological age of plants and polyvariance of plant development [2, 3]. According to the concept of biological age the developmental process of every individual plant has to be divided into ontogenetic stages [4]. There are two reasons to apply this concept: 1) individual plants belonging to one species experience specific ontogenetic stages during different calendar periods, but since they are at the same stage of development, their role in the population and in the community is the same; 2) individual plants belonging to different species with different life cycles undergo the same ontogenetic stages for different periods of time. This means that in a comparative assessment of the role of trees in a cenosis it is more logical to consider not calendar age, but the level of development: the ontogenetic stage. According to the concept of polyvariance in individual development, the life cycle of organisms is diverse and dependent on a changing habitat. At the same time, a variety of cycles has specific features which are caused by the species-specific rate of response of the developing organism $[5,6]$. Because of polyvariance in their development, plants get the nutrients they need to grow as much as possible under different environmental treatment conditions, and polyvariance also underlies the sustainable development of forest communities [7].
The purpose of this paper is to compare particular features of the initial stages of tree ontogenesis in Eastern-European forests in different light intensity conditions using the concepts of biological age and polyvariance.

\section{Objects, study areas and methods of investigation}

Objects of investigation. Thirteen tree species (Betula pendula Roth, Ulmus glabra Huds., Carpinus betulus L., Quercus robur L. Picea abies (L.) Karst., Salix caprea L., Acer platanoides L., A. campestre L., A. tataricum L., Tilia cordata Mill., Populus tremula L., Pinus sylvestris L. and Fraxinus excelsior $\mathrm{L}$.) were chosen as the main objects of investigation in broadleaved and coniferous-broadleaved forests in Eastern Europe.

Study areas. The main investigations were carried out in the hornbeam forests of the Kanevsky Nature Reserve in the Cherkassy Region (Ukraine) and additional studies were conducted in sprucebroadleaved and pine forests in the Bryansk Forest Nature Reserve (in Russian: Zapovednik «Bryansky Les») (Bryansk Oblast, Russia). In botanicalgeographical terms, Kanevsky Nature Reserve belongs to the Middle Dnepr subprovince of the Eastern European forest-steppe ecoregion [8]. The choice of hornbeam forests as the main object of the study was not accidental: in these communities light intensity at the level of the undergrowth is on average $1 \%$ of that found in the open due to the low light penetration through the crowns of C. betulus [9]. Experimental research in forests with similar light conditions found two clear results: 1) isolation of the root system of adult trees does not improve the vital status of the trees in the undergrowth; 2) mobile forms of mineral nutrients are underexploited by stunted trees [10-12]. In other words, the survival of plants in the under- 
growth in dark hornbeam forests depends on the adaptation of trees to low light intensity. The Bryansk Forest Nature Reserve is situated in the area of broadleaved forests (mixed with $P$. abies in small numbers) which belong to the Polesie subprovince of the Eastern European province belonging to the European broadleaved forest region [8].

Methods. The concept of the biological age of plants is at the core of research on undergrowth development. Further, we based our analysis on periods of ontogenesis, which have been proposed for trees $[3,13,14]$. Ontogenetic stages were designated as follows: $p$ - seedlings, $j$ - juvenile, $i m_{l}$, $\mathrm{im}_{2}$ - first and second immature subgroups, $v_{1}, v_{2}-$ first and second virginile subgroups, $g_{1}, g_{2}, g_{3}$ young, middle-aged and old generative individuals, $s$ - senile. In $j, i m_{1}, i m_{2}, v_{1}$ and $v_{2}$ trees, the following biological features were analysed: average annual biomass growth, specific density of the leaf area $(S D L)$, net assimilation, features of the growth of the above-ground axis including height, crown characteristics, absolute (calendar) age, ability to progress to quasi-senile $(q s)$ state and development rate. These attributes were evaluated in undergrowth species with low vitality, which existed at minimal light level. The appearance of these plants is shown in Figures 3, 5, 6, and 7, as well as in previous publications [13-15].

Minimum light intensity is the lowest light intensity at which the undergrowth can still exist [1]. Minimum light intensity was determined with a LX1010BS photometer in mid-summer. Illumination was measured above individuals with low vitality every hour from 9 a.m. to 6 p.m. for several sunny days. At the same time total irradiance in the open was determined. The values of irradiance over individuals were expressed as a percentage of the total light from the open. The undergrowth chosen was in the most shaded areas of the forest with optimal conditions of watering and mineral nutrition, following Tsyganov's ecological scales [16]. The shoot and root systems of individuals were not broken. The most suitable conditions for undergrowth species T. cordata, F. excelsior and U. glabra were hornbeam forests with Aegopodium podagraria $L$. dominant in the field layer. For undergrowth species Acer platanoides and A. campestre hornbeam forests with a dominance of Carex pilosa Scop. and Aegopodium podagraria L. in the field layer were most hospitable. For undergrowth species $C$. betulus and A. tataricum forests with dominance of Poa nemoralis L. and Carex pilosa Scop. were most suitable. For undergrowth species $S$. caprea, B. pendula, $P$. tremula and $P$. abies treefall gaps of different sizes with deadwood were best and for $P$. sylvestris and $Q$. robur green moss pine forests were most favourable.
Average annual biomass growth (production or productivity) was calculated using the formula:

$$
P=\frac{W p}{A}+W l,
$$

where $P$ is the productivity, $W p$ is the mass of the perennial parts of the plant (stems and roots), $W l$ is the mass of the leaves and $A$ is the age of the plant in years. Net assimilation and specific leaf density, additional indicators which plant production depends on, were also determined. Net assimilation $(N A)$ is the rate of accumulation of organic matter in plant tissues, calculated as intake per unit area, or leaf mass, minus those organic matter that were spent on respiration during the period of study [17]. In this study $N A$ was calculated per year and per unit leaf area:

$$
N A=\frac{P}{S l},
$$

where $S l$ is the leaf area. Specific density of leaves $(S D L)$ is the mass per unit leaf area, which is closely related to the intensity of photosynthesis [18]. $S D L$ values for $P$. sylvestris and $P$. abies were calculated according to the method proposed by Tselnicker [19]. All mass parameters were determined after air-drying.

Minimum light intensity for each species at ontogenetic stages $j, i m_{1}, i m_{2}$ and $v_{2}$ was measured in $32-181$ replicates. The average annual biomass growth, leaf area and $S D L$ for each species in ontogenetic stages $j, i m_{1}, i m_{2}$ and $v_{2}$ and under all conditions were determined in 4-49 replicates. The following statistical parameters were determined: arithmetic mean $(M)$, mean error $(m)$, standard deviation $(\sigma)$, among others. The $\chi^{2}$ (chisquare) test was used to test data for normal distribution. For pairwise comparison of normally distributed independent samples, Student's T Test was used. For pairwise comparison of disconnected samples that are subjected to the normal distribution, Student's criterion was used. For pairwise comparison of independent samples of small quantities, the non-parametric Mann-Whitney test was used [20]. Detailed statistical processing of the material was provided earlier [7].

\section{Results}

Aspects of undergrowth development at permanent minimum light intensity. The degree of undergrowth development in the forest is determined by the level of light intensity. Studies have revealed two aspects to this development. Firstly, the more light available in the habitat, the greater the level of ontogenetic development, for example 
Q. robur develops only to the $j$ stage at light intensity of $1.2 \%$ (of the total light available), but reaches $i m_{1}$ at $2.6 \%, i m_{2}$ at $4.5 \%$ and the $v_{2}$ stage only at $10.4 \%$. Secondly, in conditions of light deficit (minimum light intensity), plant development can linger for many years in each of these ontogenetic stages (Fig. 1).

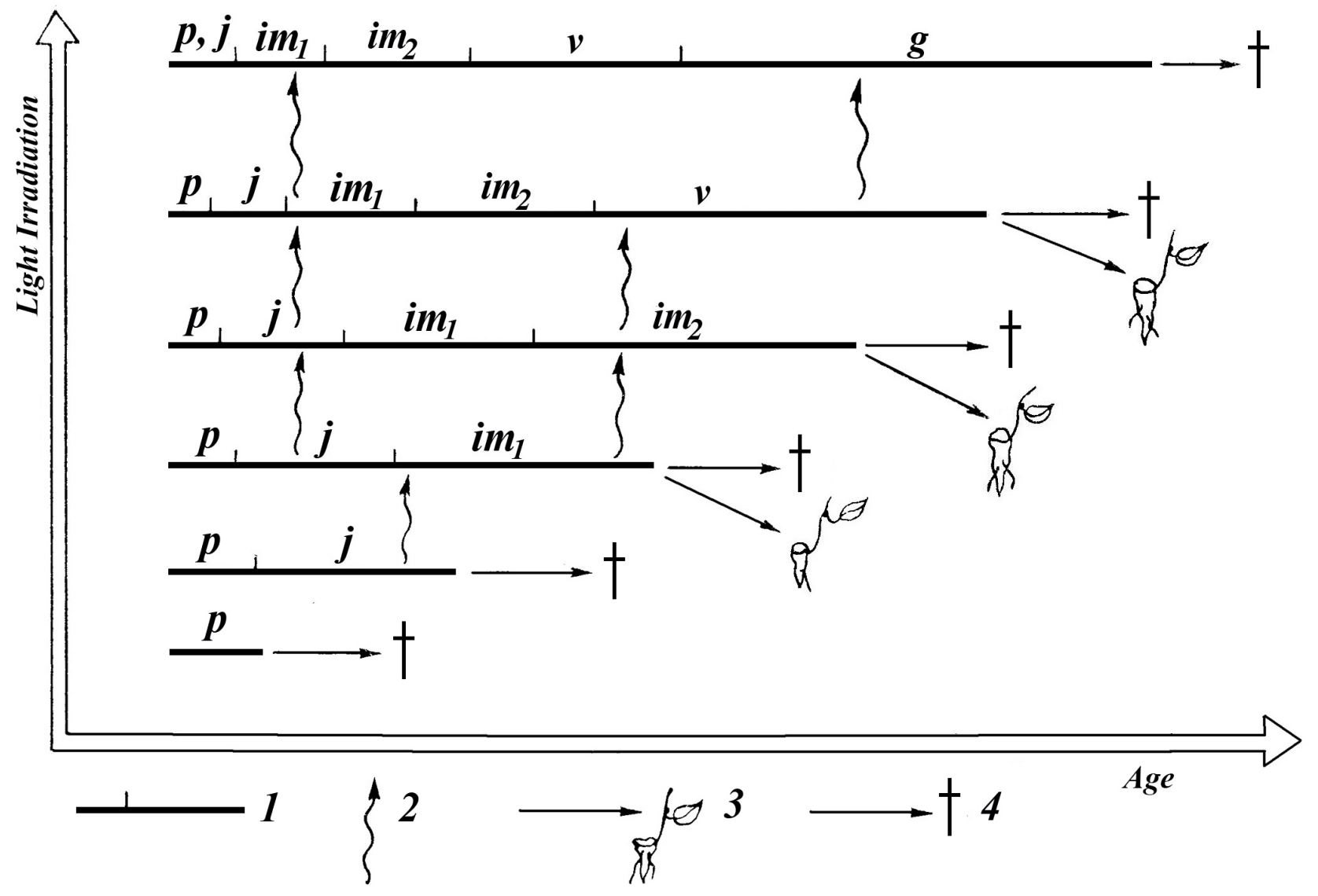

Fig. 1. Scheme representing development of trees in a forest under different light conditions [21]. Ontogenetic stages: $p$ - seedling; $j$ - juvenile; $\mathrm{im}_{1}, \mathrm{im}_{2}$ - immature, first and second subgroups; $v$ - virginile; $g$ generative. 1 - development at constant irradiance mode at light minimum (dashes - boundaries between ontogenetic stages); 2 - transition from one stage to another with improved light conditions (after treefall gap forms); 3 - transition to quasi-senile (qs) state ("snag"); 4 - death

First, we will analyse those processes that occur in the course of calendar aging of the undergrowth, in conditions of light intensity which is constant and insufficient for further increase, i.e. at minimum light intensity. These age-related changes are common to all trees and underlie the vital activity of the undergrowth species in the forest. Plant physiologists have shown that a positive balance of organic matter, where the photosynthetic yield is greater than what is required for respiration, is necessary for the normal development of individuals [18, 22-24]. Only under these conditions can new growth occur in the plant: the appearance of branches of new orders in the root and shoot systems, which leads to an increase in absorption surfaces. This contributes to the transition of individuals to subsequent ontogenetic stages, i.e. their development. However, with constant minimum light intensity, the ontogenetic stage of the plant does not change, the plant does not develop. Only the calendar age of the individual increases, in the course of which the positive balance of organic matter decreases progressively, as the proportion of respiring parts - the roots, stems, and trunk - increases $[1,22,25]$. Eventually, the plant dies (see Fig. 1).

The data obtained during our study of the $j$ and $\mathrm{im}_{l}$ development stages in undergrowth species are in good agreement with those reported by physiologists in the publications cited above and showed that in individuals growing in conditions of minimum light intensity in the course of calendar aging the proportion of leaves decreases and the proportion of respiring parts increases (Fig. 2A). The reduction of leaves has a negative effect on the balance of organic matter. Age-associated decay in net assimilation may be an indirect indicator of the decrease in the positive balance of organic matter in conditions of limited available light (Fig. 2B). As a result, there comes a moment in the life of the plant when the balance becomes zero or even nega- 
tive. A zero organic matter balance corresponds to the compensation point on the light curve of photosynthesis. In this case, all substances formed during photosynthesis are absorbed by the respiring parts and there is no more left for further development. At this moment, the processes of growth are replaced by processes of destruction, manifested in a gradual decrease in annual height increments (Fig. 2C), a decrease in the number of lateral axes in the shoot system (Fig. 3) and in a reduction of the assimilating plant surface (Table 1), as well as in a change of course in individuals' growth in terms of height (Fig. 2D).

The undergrowth's height growth course, at minimum light intensity, is reflected by an
$S$-shaped curve (see Fig. 2D), which displays the age dynamics of the balance of organic matter. In the first years of life, when there are few respiring parts and, accordingly, a high positive balance of resources, the plant has an opportunity to increase its absorption surface. Naturally, this leads to acceleration of growth in height but in the final stages of growth, with an increase in the proportion of respiring parts and a decrease in the positive balance, the height increase diminishes and the $S$-shaped curve flattens out. With time, the plant has a negative balance, withered side branches appear (see Fig. 3) and, as a result, the plant dies.
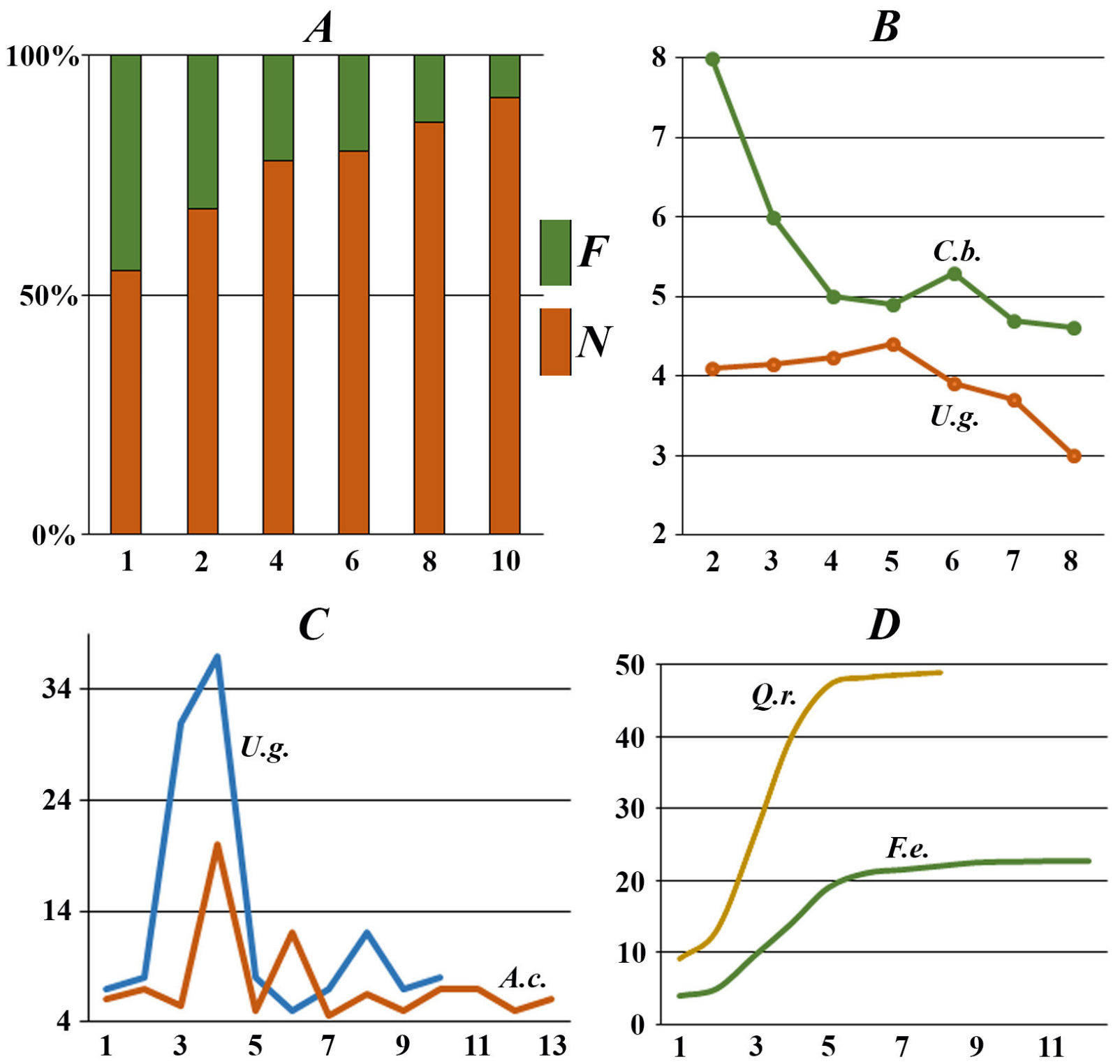

Fig. 2. Absolute age ( $x$-axis) and change of biological parameters of undergrowth plants ( $y$-axis) growing in minimum light below the forest canopy. $Y$-axis: $A$ - the ratio (\%) of the mass of photosynthetic $(F)$ and nonphotosynthetic $(N)$ parts of $j$ individuals of Acer platanoides; $B$ - net assimilation $\left(\mathrm{mg} \mathrm{cm}^{-2}\right.$ year $\left.{ }^{-1}\right)$ of $j$ individuals of Carpinus betulus (C.b.) and Ulmus glabra (U.g.); C - annual increments in height (cm) of im individuals of Ulmus glabra (U.g.) and Acer campestre (A.C.); D - growth in height (cm) of im, individuals of Quercus robur (Q.r.) and Fraxinus excelsior (F.e.) 
These examples show that in conditions of low light intensity the gradual decrease in vitality and subsequent death of plants in the undergrowth is caused by to lack of light. It is obvious that the decline in vitality and death of the undergrowth spe- cies at all ontogenetic stages at minimum light intensity reflects the general pattern of development of the younger generation of trees in closed forests (see Fig. 1).

Table 1

Change of biomorphological parameters with increase in absolute age of $i_{1}$ individuals of Tilia cordata under minimum light ( $0.7 \%$ of full light in the open), $M \pm m_{M}$

\begin{tabular}{|c|c|c|c|c|c|c|c|c|}
\hline \multirow{2}{*}{ Parameters } & \multicolumn{8}{|c|}{ Age, years } \\
\hline & $1-3$ & 4 & 5 & 6 & 7 & 8 & 9 & 10 \\
\hline $\begin{array}{l}\text { Average increment } \\
\text { in height, } \mathrm{cm}^{\cdot} \text { year }^{-1}\end{array}$ & $12 \pm 1.5$ & $8 \pm 1.1$ & $8 \pm 2.0$ & $7 \pm 0.6$ & $5 \pm 0.2$ & $6 \pm 0.9$ & $4 \pm 0.4$ & $4 \pm 0.1$ \\
\hline $\begin{array}{l}\text { Net assimilation, } \\
\mathrm{mg} \cdot \mathrm{sm}^{-2} \cdot \mathrm{year}^{-1}\end{array}$ & $3.3 \pm 0.20$ & $3.7 \pm 0.20$ & $3.1 \pm 0.10$ & $3.3 \pm 0.20$ & $3.0 \pm 0.20$ & $3.0 \pm 0.20$ & $3.0 \pm 0.20$ & $2.8 \pm 0.20$ \\
\hline Area of leaves, $\mathrm{cm}^{2}$ & \multicolumn{3}{|c|}{$717 \pm 192.0$} & \multicolumn{3}{|c|}{$652 \pm 58.0$} & \multicolumn{2}{|c|}{$593 \pm 85.0$} \\
\hline $\begin{array}{l}\text { Productivity, } \\
\text { mg:year }^{-1}\end{array}$ & \multicolumn{3}{|c|}{$1208 \pm 159.0$} & \multicolumn{3}{|c|}{$1073 \pm 100.0$} & \multicolumn{2}{|c|}{$971 \pm 164.0$} \\
\hline
\end{tabular}

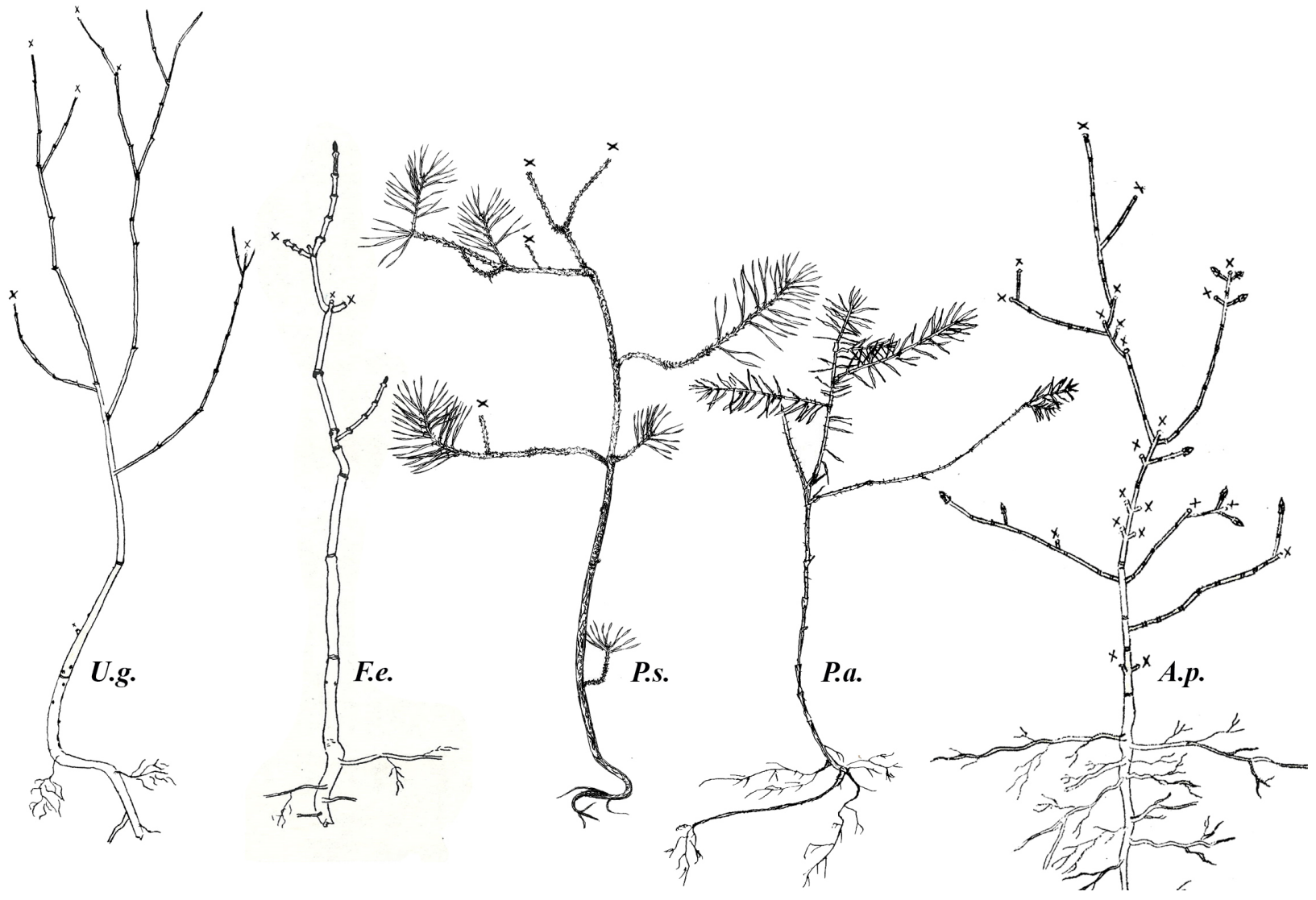

Fig. 3. The appearance of $\mathrm{im}_{1}$ trees in the undergrowth in minimum light below the forest canopy.

U.g. - 11-year-old Ulmus glabra; F.e. - 13-year-old Fraxinus excelsior; P.s. - 8-year-old Pinus sylvestris

(picture by N. A. Tatarenkova); P.a. - 12-year-old Picea abies (picture by A. M. Romanovsky); A.p. - 18-year-old Acer platanoides. Crosses - dead shoots

Minimum light intensity for undergrowth trees. Minimum light intensity is the lowest light intensity at which plants in the undergrowth can survive, corresponding to the level of light at which a positive balance is still possible between the formation of organic matter during photosynthesis and spending it on necessary life processes [1]. This im- plies that a small positive balance ensures the plant's survival. In the study, minimum light intensity was measured over individuals of extremely low vitality, growing in forest conditions: this level of illuminance is close to the compensation point on the light curve of the organism's productivity $[18,26]$. Minimum light intensity can be used as a 
fundamental indicator of shade tolerance. Shade tolerance is the lower limit of the plant's light and production capabilities [15, 27, 28].

The measurement of minimum light intensity showed that each species has its own tolerance limit for low light levels. It does not remain constant throughout life: the values of the minimum light intensity required increase as the tree develops, i.e. with its transition to subsequent ontogenetic stages (Table 2). This is consistent with the foresters' perception that the shade tolerance of the undergrowth decreases with age [1]. They associate shade tolerance reduction with an increase in the proportion of non-photosynthesizing (respiring) parts of the plant: roots, stems and trunk. Our studies have shown that the proportion of leaves in the total mass of an individual decreases with calendar or biological age in all tree species (Fig. 4). In other words, a plant in the undergrowth needs more and more light as it develops to maintain its respiring parts and, consequently, to survive (see Fig. 1).

Based on the values of their minimum light intensity requirement, a ranking of species was compiled according the decrease of their shade tolerance at different stages of ontogenesis (Table 3 ).
Comparison of shade tolerance scale values makes it possible to identify several groups of species that have similar shade tolerance and similar mechanisms of development. The first group includes $P$. sylvestris, B. pendula, $P$. tremula, $S$. caprea and $Q$. robur. They exhibit the highest demand for light at all ontogenetic stages (Table 3 ), shown by the highest values of minimum light intensity (see Table 2). Furthermore, plant physiologists note that representatives of this group are characterized by relatively low lability of the photosynthetic apparatus, and also by the fact that the compensation point on their photosynthesis light curve is positioned at high light intensity [18, 22]. In these undergrowth communities the light intensity corresponding to the lower limit of tolerance for these species arises only at the fall of multiple old trees $[29,30]$ or in park-type forests with sparse canopies. These species do not occur in the undergrowth under the canopy of forest casting deep shade $[7,31,32]$. The recognition of low shade tolerance in $P$. sylvestris, $B$. pendula, $P$. tremula, $S$. caprea and $Q$. robur goes back to the classic works of forestry [33-36].

Table 2

Light minima of undergrowth trees at different ontogenetic stages (\% of full light in the open)

\begin{tabular}{|c|c|c|c|c|c|c|c|c|}
\hline \multirow{3}{*}{ Tree species } & \multicolumn{8}{|c|}{ Ontogenetic stages } \\
\hline & \multicolumn{2}{|c|}{$j$} & \multicolumn{2}{|l|}{$i m_{1}$} & \multicolumn{2}{|l|}{$i m_{2}$} & \multicolumn{2}{|l|}{$\overline{v_{2}}$} \\
\hline & $M \pm m_{M}$ & $\sigma$ & $M \pm m_{M}$ & $\sigma$ & $M \pm m_{M}$ & $\sigma$ & $M \pm m_{M}$ & $\sigma$ \\
\hline Acer platanoides & $\begin{array}{c}0.28 \pm \\
0.017 \\
\end{array}$ & 0.129 & $0.36 \pm 0.008$ & 0.057 & $0.45 \pm 0.011$ & 0.099 & $0.78 \pm 0.021$ & 0.231 \\
\hline Fraxinus excelsior & $\begin{array}{c}0.38 \pm \\
0.008\end{array}$ & 0.089 & $0.50 \pm 0.012$ & 0.112 & $0.88 \pm 0.020$ & 0.244 & $4.19 \pm 0.202$ & 1.264 \\
\hline Acer campestre & $\begin{array}{c}0.42 \pm \\
0.014 \\
\end{array}$ & 0.131 & $0.48 \pm 0.011$ & 0.116 & $0.58 \pm 0.014$ & 0.153 & $0.96 \pm 0.029$ & 0.189 \\
\hline Ulmus glabra & $\begin{array}{l}0.48 \pm \\
0.023\end{array}$ & 0.200 & $0.58 \pm 0.019$ & 0.176 & $0.66 \pm 0.019$ & 0.225 & $1.08 \pm 0.073$ & 0.518 \\
\hline Acer tataricum & $\begin{array}{c}0.55 \pm \\
0.011\end{array}$ & 0.135 & $0.85 \pm 0.027$ & 0.329 & $1.49 \pm 0.039$ & 0.389 & $3.15 \pm 0.122$ & 1.174 \\
\hline Tilia cordata & $\begin{array}{c}0.60 \pm \\
0.018 \\
\end{array}$ & 0.178 & .022 & 0.196 & $0.81 \pm 0.027$ & 0.261 & $0.98 \pm 0.037$ & 0.305 \\
\hline Carpinus betulus & $\begin{array}{c}0.71 \pm \\
0.019\end{array}$ & 0.176 & $1.47 \pm 0.083$ & 0.594 & $1.50 \pm 0.021$ & 0.144 & $1.84 \pm 0.104$ & 0.770 \\
\hline Picea abies & $\begin{array}{l}1.04 \pm \\
0.029 \\
\end{array}$ & 0.253 & $1.06 \pm 0.030$ & 0.338 & $1.17 \pm 0.019$ & 0.181 & $1.33 \pm 0.032$ & 0.383 \\
\hline Querc & $\begin{array}{l}1.21 \pm \\
0.083 \\
\end{array}$ & 0.523 & $2.60 \pm 0.238$ & 1.484 & $4.47 \pm 0.186$ & 1.231 & $\begin{array}{c}10.36 \pm \\
0.314 \\
\end{array}$ & 0.631 \\
\hline Salix c & $\begin{array}{l}1.50 \pm \\
0.100 \\
\end{array}$ & 0.820 & $2.75 \pm 0.180$ & 1.414 & $6.40 \pm 0.287$ & 2.527 & $\begin{array}{c}13.87 \pm \\
1.312 \\
\end{array}$ & 8.400 \\
\hline Populus tremula & $\begin{array}{c}2.67 \pm \\
0.055 \\
\end{array}$ & 0.366 & $4.27 \pm 0.278$ & 1.822 & $6.60 \pm 0.385$ & 2.342 & $\begin{array}{c}17.85 \pm \\
1.901 \\
\end{array}$ & 10.756 \\
\hline Betula pendula & $\begin{array}{c}3.09 \pm \\
0.081\end{array}$ & 0.642 & $4.51 \pm 0.192$ & 1.720 & $9.62 \pm 0.198$ & 1.428 & $\begin{array}{c}22.98 \pm \\
1.264 \\
\end{array}$ & 9.710 \\
\hline Pinus sylvestris & $\begin{array}{c}6.01 \pm \\
0.139\end{array}$ & 1.356 & $\begin{array}{c}11.00 \pm \\
0.358\end{array}$ & 4.817 & $\begin{array}{c}13.89 \pm \\
0.359\end{array}$ & 2.280 & $\begin{array}{c}34.27 \pm \\
2.720\end{array}$ & 16.545 \\
\hline
\end{tabular}

Note: $M$ - arithmetic mean, $m_{M}-$ average error, $\sigma-$ mean of square deviation. 
Betula pendula

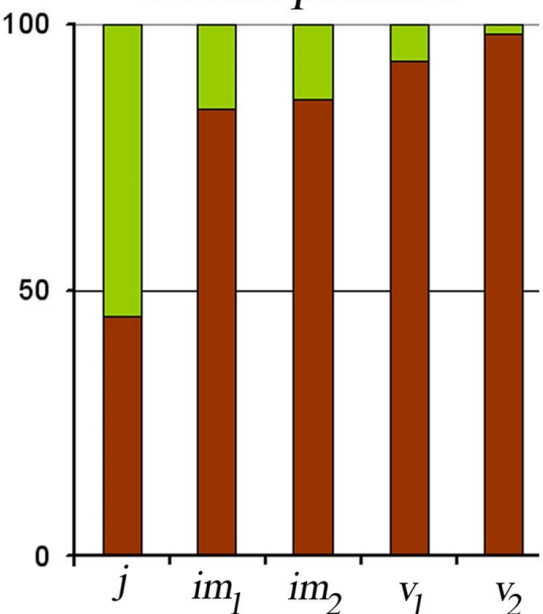

Carpinus betulus

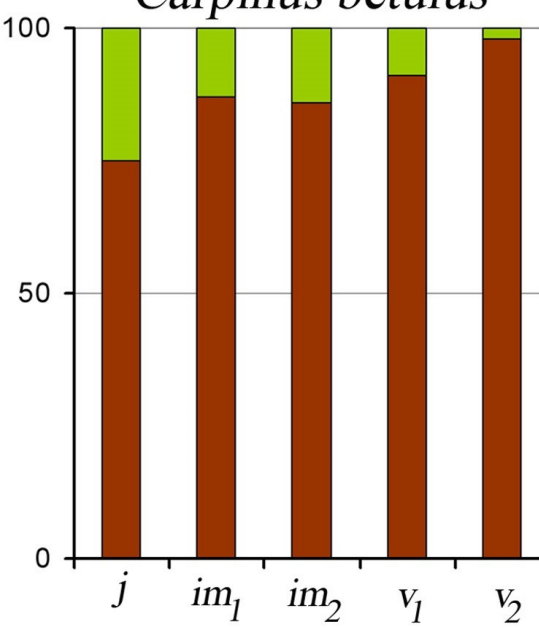

Acer platanoides

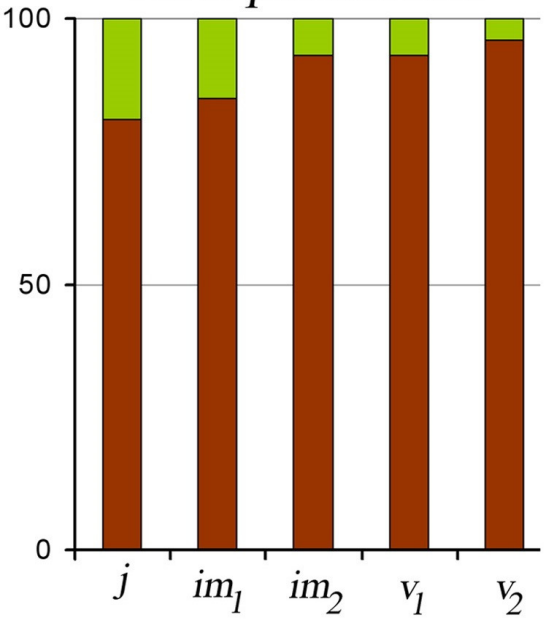

Quercus robur

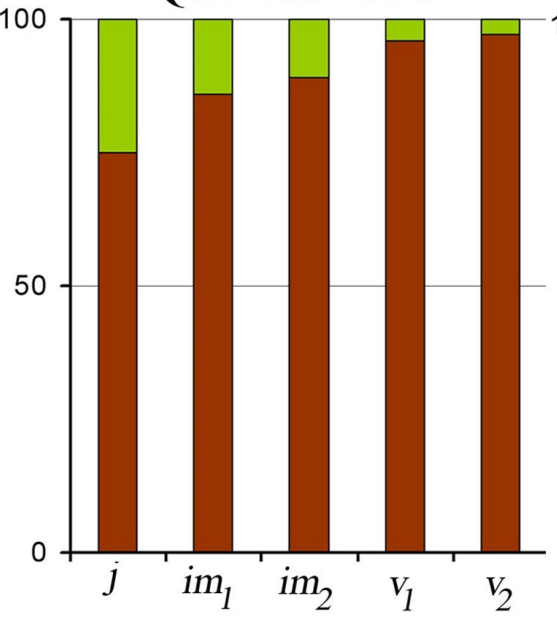

Ulmus glabra

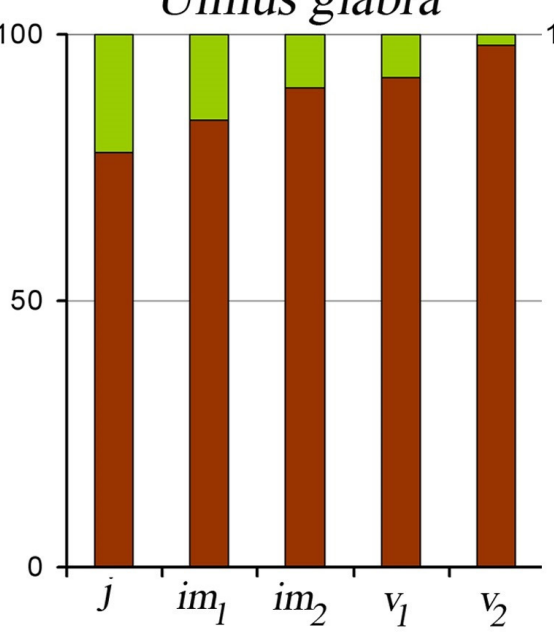

Acer campestre

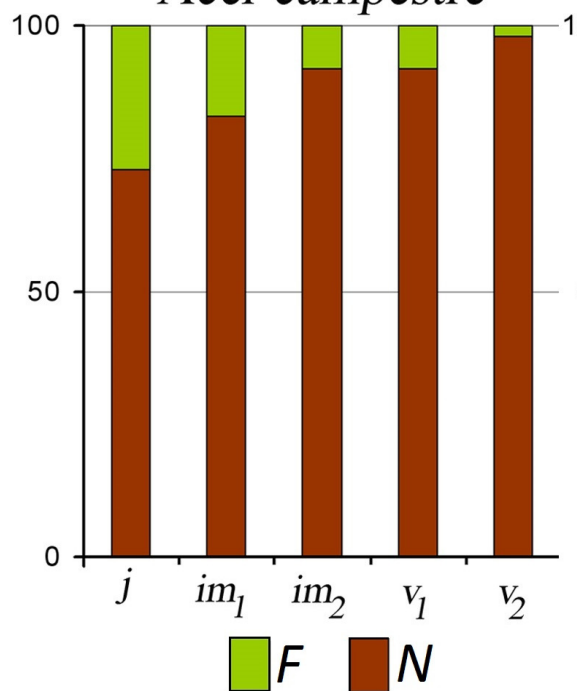

Fraxinus excelsior

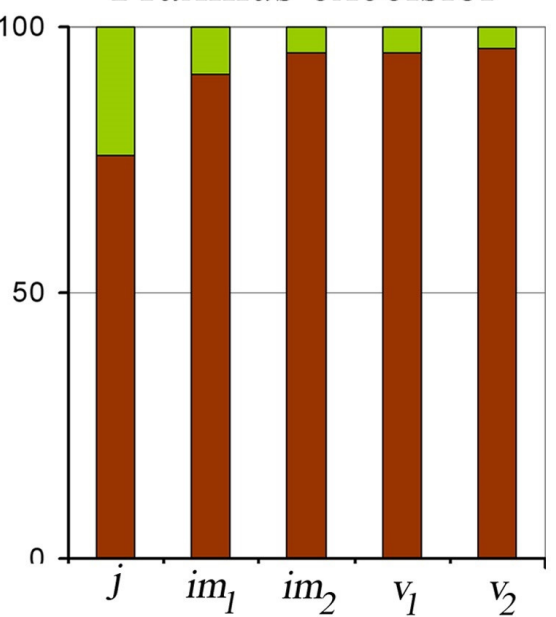

Tilia cordata

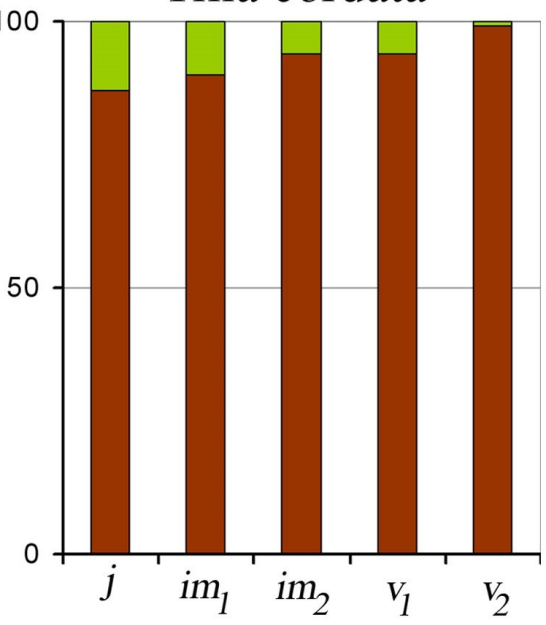

Acer tataricum

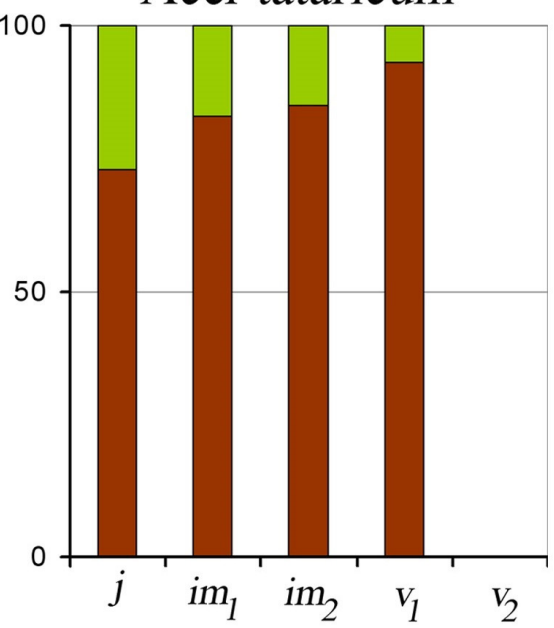

Fig. 4. Change in the ratio of the mass of photosynthetic $(F)$ and non-photosynthetic $(N)$ plant parts in minimum light below the forest canopy. The x-axis represents ontogenetic stages, while the $y$-axis represents percentages. Ontogenetic stages: $j$ - juvenile, $i_{1}$ - first immature subgroup, $\mathrm{im}_{2}$ - second immature subgroup, $v_{1}$ - first virginile subgroup, $v_{2}-$ second virginile subgroup 
Shade tolerance scales of East European tree species at different ontogenetic stages. The scales are compiled on the basis of the light minimum of the undergrowth (Table 2). The most shade-tolerant species are at the beginning and the most shade-intolerant species are at the end of the list

\begin{tabular}{|c|c|c|c|c|}
\hline \multicolumn{5}{|c|}{ Ontogenetic stages } \\
\hline Juvenile $(j)$ & $\begin{array}{c}\text { Immature plants } \\
\text { of the first subgroup } \\
\left(\mathrm{im}_{1}\right)\end{array}$ & $\begin{array}{l}\text { Immature plants } \\
\text { of the second } \\
\text { subgroup }\left(\mathrm{im}_{2}\right)\end{array}$ & $\begin{array}{l}\text { Virginile plants } \\
\text { of the first } \\
\text { subgroup }\left(v_{1}\right)^{*}\end{array}$ & $\begin{array}{l}\text { Virginile plants } \\
\text { of the second } \\
\text { subgroup }\left(v_{2}\right)\end{array}$ \\
\hline 13. Acer platanoides & 13. Acer platanoides & 13. Acer platanoides & 13. Acer platanoides & 13. Acer platanoides \\
\hline $\begin{array}{l}\text { 12. Fraxinus } \\
\text { excelsior }\end{array}$ & 12. Acer campestre & 12. Acer campestre & 12. Acer campestre & 12. Acer campestre \\
\hline 11. Acer campestre & $\begin{array}{l}\text { 11. Fraxinus } \\
\text { excelsior }\end{array}$ & 11. Ulmus glabra & 11. Ulmus glabra & 11. Tilia cordata \\
\hline 10. Ulm & 10. Ulmus glabra & 10. Tilic & 10. Tilia & $10 . \mathrm{Ul}$ \\
\hline 09. Acer tataricum & 09. Tilia cordata & $\begin{array}{l}\text { 09. Fraxinus } \\
\text { excelsior }\end{array}$ & 09. Picea abies & 09. Picea abies \\
\hline 08. Tilia cordata & 08. Acer tataricum & 08. Picea abies & 08. Acer tataricum & 08. Carpinus betulus \\
\hline 07. Carpinus betulus & 07. Picea abies & 07. Acer tataricum & $\begin{array}{l}\text { 07. Fraxinus } \\
\text { excelsior }\end{array}$ & 07. Acer tataricum \\
\hline 06. Picea & 06. Carpinus betulus & 06. Carpinus betulus & 06. Carpinus betulus & $\begin{array}{l}\text { 06. Fraxinus } \\
\text { excelsior }\end{array}$ \\
\hline 05. Quercus robur & 05. Quercus robur & 05. Quercus robur & 05. Quercus robur & 05. Quercus robur \\
\hline 04. Salix caprea & 04. Salix caprea & 04. Salix caprea & 04. Salix caprea & 04. Salix caprea \\
\hline 03. Populus tremula & 03. Populus tremula & 03. Populus tremula & 03. Populus tremula & 03. Populus tremula \\
\hline 02. Betula & 02. Betula & 02. Betula pendula & 02. Betula & 02. Betula pendula \\
\hline 01. Pinus sylvestris & 01. Pinus sylvestris & 01. Pinus sylvestris & 01. Pinus sylvestris & 01. Pinus sylvestris \\
\hline
\end{tabular}

Note: * - based on comparison of the scales of shade tolerance at ontogenetic stages $i m_{2}$ and $v_{2}$. Groups of similar species are highlighted in the same colour. The number before the species name is order of the species in the shade tolerance scale [15].

The second group is represented by Acer platanoides, A. campestre and U. glabra and is characterized by the greatest shade tolerance at all ontogenetic stages (see Table 3). This is manifested in the smallest values of minimum light intensity (see Table 2) and plant physiologists have shown that species of this group are characterized by relatively high lability of the photosynthetic apparatus, as well as having a compensation point on their photosynthetic light curve at low light intensities $[18,22]$. They can live in the darkest habitats under the dense canopy of beech, hornbeam and maple forests $[9,37]$. The high tolerance of U. glabra, Acer platanoides and A. campestre to light deficiency is confirmed by the scales of shade tolerance that have been developed by foresters and physiologists [34-36].

The third group is composed of $C$. betulus, $A$. tataricum and $P$. abies. These tree species occupy an intermediate position in the tree sinusia according to the values of their minimum light requirement (see Table 3). The position of the species in this group changes in scales of shade tolerance arranged by ontogenetic stage: for example, at stages $j-i m_{1} A$. tataricum is the most shade tolerant, then at $v_{2}$, conversely, $C$. betulus and $P$. abies are more shade tolerant (see Table 2). The undergrowth composed of this group is more common in relatively light habitats: $C$. betulus and $A$. tataricum prefer to regenerate on the sunny slopes of southern exposures in sparse hornbeam and oak forests and $P$. abies likes to grow in treefall gaps in the coniferous-broadleaved forest $[31,38]$. It is worth noting that in some scales $C$. betulus and $P$. abies belong to the most shadetolerant trees [35-37]. However, measurements of light minima in our study (see Table 2) have shown that $C$. betulus and P. abies do not belong in the group of the most shade-tolerant trees in the Eastern European forests comprised of such trees as Acer platanoides, A. campestre and U. glabra (see Table 3). These conflicting data can easily be explained. The foresters consider the pattern of the crown of mature trees as a major criterion for judging shade tolerance: gloomy twilight forms under the dense foliage of $C$. betulus and $P$. abies even on the brightest of sunny days.

$F$. excelsior and T. cordata stand out from other tree species in these scales. These species are characterized by distinct changes in shade tolerance associated with ontogenesis (see Table 3). F. excelsior is extremely shade-tolerant and close to A. platanoides at the $j$ and $i m_{1}$ stages. However, at later stages of ontogenesis, the light requirement for this tree species increases sharply: at the $v_{2}$ stage the shade tolerance of $F$. excelsior is as low 
as that of $Q$. robur (see Table 2). The foresters have found that the light requirement for $F$. excelsior increases with the tree's age [34, 39]. The relative shade tolerance of $T$. cordata varies in the opposite direction. At the $j$ stage the shade tolerance of $T$. cordata is similar to that of $P$. abies and $C$. betulus, measured by the value of minimum light requirement. However, when reaching the $v_{2}$ stage the comparative shade tolerance of $T$. cordata increases and becomes similar to that of A. platanoides and A. campestre (see Table 2, 3).

A sharp increase in the light requirements of $F$. excelsior associated with changes in ontogeny is caused by cenotic conditions. Our observations show that the high shade tolerance of $F$. excelsior at the early stages of ontogenesis $\left(j\right.$ and $\left.\mathrm{im}_{l}\right)$ is most likely due to the fact that its main regeneration niche in undisturbed (climax) forests is in wet eutrophic habitats ${ }^{1}$ with well-developed tall herbs layer, under the canopy of which deep shade occurs $[41,42]$. To survive in these conditions requires significant shade tolerance, which $F$. excelsior has. However, with exit from the tall herb layer and transition to the virginile ontogenetic stage the crown of $F$. excelsior emerges into the upper well-lit layers of the forest, where high shade tolerance is of little significance. The studies we conducted in well-preserved swamp tall-herb, spruce and alder forests showed that average light intensity under the canopy of tall herbs in the daytime was $0.5 \%$ of the total available and above the tall herbs it was $40.0 \%$. Apparently, such sharp change in light conditions is indicative of all tallherb forests within a well-developed gap mosaic structure [43].

Average annual increase in biomass of undergrowth trees. Minimal average annual increment of biomass determined in sublethal individuals at minimum light is near to the compensation point on the light curve of photosynthesis. Increase in biomass can be used to analyse the shade tolerance of undergrowth species: the lower the increase in the biomass under the canopy of the forest the lower the light compensation point and the higher shade tolerance of the plant $[7,44]$. However, this measure should only be used for characterizing groups of species with similar physiological mechanisms of shade tolerance: the limited use of this parameter is due to the fact that plant productivity in the forest also depends on efficiently of using weak light energy in photosynthesis $[18,45$, 46]. A plant of one tree species in the undergrowth, living in low light, may have higher levels of biomass increase than another existing at higher light flux. For example, the average annual increase of

\footnotetext{
${ }^{1}$ Many researchers describe Fraxinus excelsior as a species that needs soil moisture and soils with high fertility [36, 40, 47, 48].
}

the biomass of stage $v_{2} U$. glabra in the undergrowth, which lives at $1 \%$ of total available illumination, is almost twice the increase of the biomass at stage $v_{2}$ of $F$. excelsior at $4 \%$ illumination [7]. In other words, virginal U. glabra uses low illumination to form biomass efficiently, unlike F. excelsior.

Two groups of species can be characterized by average annual increase of biomass at all ontogenetic stages. Weakly shade tolerant species (P. tremula, S. caprea, B. pendula, P. sylvestris and $Q$. robur) are at one side of the tree sinusia. In these species individuals with low vitality are characterized by relatively high biomass increase (Table 4). Plant physiologists and ecologists have shown that representatives of these species have high rates of dark respiration $[18,22,49-51]$. At this level of "consumption" persistence of undergrowth plants under the canopy of the forest is possible only at high levels of productivity. In turn, high productivity can only be maintained in communities with the highest levels of light. Thus, relatively high productivity determines weak shade tolerance in the species of this group.

On the other side of the tree sinusia is the group of shade-tolerant species: F. excelsior, U. glabra, T. cordata, P. abies, C. betulus, Acer tataricum, A. campestre and $A$. platanoides. In contrast to the previous group, they are characterized by lower values of biomass increase with shortage of light (see Table 4). Physiologists recognize that the representatives of these species have a relatively low level of respiration at limited illumination $[18,24$, 49-53]. A low level of "consumption" allows them to exist in the darkest communities, satisfied with relatively little productivity. Thus, the high shade tolerance of the species in this group is based on relatively low productivity.

Thus, using the average annual increase of biomass, determined in the undergrowth species that were grown in light deficit, it is possible to distinguish two groups of species which have comparable shade tolerance and similar mechanisms of production. It has been shown that differences between these groups are so great that differences in the average annual biomass increase are statistically significant [7].

Specific density of leaves $(S D L)$ in the undergrowth. $S D L$ is the unit mass of the leaf area, which is closely connected to photosynthetic intensity. Physiologists have found that higher $S D L$ is associated with higher photosynthetic intensity [18]. This index is causally related to the vertical gradient of illumination in the forest as well as to the horizontal variation of its light field. The consequence of vertical increase of illumination in the community is an ontogeny-related increase in $S D L$ of the plants in the undergrowth and, accordingly, the intensity of their photosynthesis. At the first 
stages of ontogenesis, all the trees are characterized by relatively thin leaf blades with small values of SDL (Table 5). This ensures the most efficient use of the limited light available for photosynthesis in the lower forest layers. At later stages of onto- genesis, the undergrowth species grow into the more highly illuminated layers, forming relatively thick leaf blades with higher $S D L$ that are adapted to absorb light at higher intensity and also have high photosynthetic intensity.

Table 4

Average annual biomass increase $\left(g \cdot y^{-1}{ }^{-1}\right)$ of trees in the undergrowth under a dense forest canopy in minimum light at different ontogenetic stages

\begin{tabular}{|l|c|c|c|c|c|c|}
\hline \multirow{2}{*}{ Tree species } & \multicolumn{7}{|c|}{ Ontogenetic stages } \\
\cline { 2 - 7 } & \multicolumn{2}{|c|}{$j$} & \multicolumn{2}{c|}{$i m_{1}$} & \multicolumn{2}{c|}{$i m_{2}$} \\
\cline { 2 - 7 } & $M \pm m_{M}$ & $N$ & $M \pm m_{M}$ & $N$ & $M \pm m_{M}$ & $N$ \\
\hline Salix caprea & $1.52 \pm 0.104$ & 4 & $3.52 \pm 0.165$ & 10 & $35.3 \pm 3.43$ & 13 \\
\hline Quercus robur & $0.86 \pm 0.129$ & 19 & $2.65 \pm 0.334$ & 17 & $47.3 \pm 6.05$ & 15 \\
\hline Populus tremula & $0.82 \pm 0.030$ & 9 & $3.90 \pm 0.135$ & 10 & $40.2 \pm 4.13$ & 11 \\
\hline Betula pendula & $0.79 \pm 0.190$ & 4 & $4.50 \pm 0.956$ & 9 & $36.1 \pm 4.33$ & 17 \\
\hline Pinus sylvestris & $0.26 \pm 0.034$ & 16 & $2.37 \pm 0.102$ & 10 & $44.7 \pm 2.24$ & 10 \\
\hline Tilia cordata & $0.15 \pm 0.014$ & 24 & $1.72 \pm 0.145$ & 43 & $8.5 \pm 0.61$ & 31 \\
\hline Acer tataricum & $0.13 \pm 0.014$ & 16 & $1.69 \pm 0.129$ & 49 & $8.6 \pm 0.92$ & 11 \\
\hline Acer campestre & $0.12 \pm 0.013$ & 23 & $1.47 \pm 0.094$ & 39 & $6.7 \pm 0.71$ & 27 \\
\hline Picea abies & $0.10 \pm 0.015$ & 8 & $1.18 \pm 0.107$ & 10 & $9.6 \pm 0.35$ & 10 \\
\hline Carpinus betulus & $0.06 \pm 0.003$ & 40 & $1.52 \pm 0.160$ & 34 & $12.2 \pm 0.84$ & 38 \\
\hline Acer platanoides & $0.06 \pm 0.003$ & 40 & $1.19 \pm 0.110$ & 26 & $6.8 \pm 0.41$ & 34 \\
\hline Fraxinus excelsior & $0.05 \pm 0.004$ & 40 & $0.85 \pm 0.067$ & 28 & $9.2 \pm 0.68$ & 40 \\
\hline Ulmus glabra & $0.04 \pm 0.004$ & 25 & $0.91 \pm 0.098$ & 18 & $11.4 \pm 0.73$ & 26 \\
\hline
\end{tabular}

Note: $M$ - arithmetic mean, $m_{M}$ - average error, $N$ - sample size.

The non-homogeneous horizontal structure of the cenosis, caused by variation in illumination levels, creates conditions for the uneven distribution of plants in the forest, causing differences in the conditions of their photosynthetic activity. The undergrowth formed by T. cordata, U. glabra, A. platanoides and A. campestre is characterized by the lowest values of $S D L$. Connected with this, these plants are characterized by low photosynthetic intensity and high shade tolerance. They can successfully develop in the darkest areas of cenoses, for example, under the canopy of trees with a crown casting deep shade. The leaves of $Q$. robur,
P. sylvestris, B. pendula, S. caprea and P. tremula are characterized by relatively high values of $S D L$, indicative of their high photosynthetic intensity and significant requirements for light. Due to this, their colonization of the undergrowth is limited to large felled areas and less-shaded communities. $C$. betulus and $A$. tataricum, measured by their $S D L$ values, are intermediate in the tree sinusium (see Table 5) for good reason; these species are in the middle in the shade tolerance scales (see Table 3 ). Multiple $C$. betulus and A. tataricum individuals can accumulate in forests with a well-developed treefall gap structure [54].

Specific density of leaves $(\mathrm{SDL})\left(\mathrm{mg} \cdot \mathrm{dm}^{-2}\right)$ of the trees in the undergrowth under a dense forest canopy in minimum light at different ontogenetic stages, $M \pm m_{M}$

\begin{tabular}{|l|c|c|c|c|}
\hline \multirow{2}{*}{ Tree species } & \multicolumn{4}{|c|}{ Ontogenetic stages } \\
\cline { 2 - 5 } & $j$ & $i m_{1}$ & $i m_{2}$ & $v$ \\
\hline Quercus robur & $323 \pm 10$ & $378 \pm 15$ & $423 \pm 13$ & $530 \pm 12$ \\
\hline Betula pendula & $263 \pm 10$ & $355 \pm 13$ & $431 \pm 6$ & $494 \pm 16$ \\
\hline Populus tremula & $211 \pm 20$ & $454 \pm 40$ & $514 \pm 9$ & $550 \pm 13$ \\
\hline Salix caprea & $196 \pm 1$ & $290 \pm 20$ & $441 \pm 6$ & $596 \pm 14$ \\
\hline Pinus sylvestris & $158 \pm 5$ & $234 \pm 6$ & $283 \pm 3$ & $460 \pm 21$ \\
\hline Fraxinus excelsior & $189 \pm 3$ & $201 \pm 5$ & $210 \pm 4$ & $316 \pm 11$ \\
\hline Carpinus betulus & $264 \pm 3$ & $269 \pm 11$ & $290 \pm 12$ & $295 \pm 8$ \\
\hline Ulmus glabra & $209 \pm 5$ & $204 \pm 2$ & $229 \pm 7$ & $293 \pm 4$ \\
\hline Acer tataricum & $260 \pm 5$ & $280 \pm 4$ & $305 \pm 5$ & $321 \pm 9$ \\
\hline Acer campestre & $239 \pm 8$ & $225 \pm 8$ & $266 \pm 5$ & $282 \pm 8$ \\
\hline Acer platanoides & $219 \pm 4$ & $203 \pm 3$ & $217 \pm 8$ & $231 \pm 6$ \\
\hline Tilia cordata & $165 \pm 2$ & $171 \pm 2$ & $175 \pm 2$ & $217 \pm 6$ \\
\hline Picea abies & $70 \pm 1$ & $70 \pm 1$ & $192 \pm 6$ & $303 \pm 6$ \\
\hline
\end{tabular}

Note: $M$ - arithmetic mean, $m_{M}-$ average error. 
Special attention should be paid to $F$. excelsior and its $S D L$. A significant ontogenetic increase of $F$. excelsior's light requirement is accompanied by subsequent changes in the structure of the leaf and its functions. At the $j$ and $i m_{1}$ stages $F$. excelsior is characterized by low values of $S D L$ and, correspondingly, low photosynthetic intensity: this allows $F$. excelsior to oecize in the darkest places, for example, under the canopy of tall herbs. However, $F$. excelsior on transition into the $v$ ontogenetic stage leaves the tall herb layer, entering the well-illuminated layers of the forest. $S D L$ and, therefore, photosynthetic intensity increases sharply relative to the other broad-leaved trees (see Table 5). These physiological changes entail a significant decrease in shade tolerance with age. Simultaneously, this fact testifies to the singularity of the communities in which $F$. excelsior develops. These cenoses are characterized by a sharp, abrupt increase in illumination as the plant grows up through the community, which is probably typical for tall forest herbs.

Peculiarities in the appearance of the aerial axis of undergrowth trees. The undergrowth growing at minimum light is characterized by a peculiar development in the aerial axis; in all cases the growth of the axis is wavy (Fig. 2C). A decline in growth "waves" is accompanied by sympodial branching and sharp decreases in the values of annual increments. Sympodial branching means part of the shoot system has died due to excessive shading and a new shoot from axillary buds closest to the apex has replaced it. Sympodial branching is the result of a negative balance of organic matter, when organic matter formed during photosynthesis is not enough to fuel the shoots' respiration. Sympodial branching is important for the species of the undergrowth since elimination of the extant shoots contributes to the maintenance of positive balance for longer and, consequently, extension of the life of the plant in the forest. The rise of growth "waves" is associated, as a rule, with improved illumination under the forest canopy as a result of the occurrence of a small treefall gap in the upper layer.

Undergrowth species vary in their number of growth "waves". Shade-tolerant species have more of them: for example, there are up to ten waves in A. platanoides, at the $\mathrm{im}_{2}$ ontogenetic stage, up to seven in $A$. campestre, up to five in $F$. excelsior and $T$. cordata and up to four in $C$. betulus and $U$. glabra. The slightly shade-tolerant species (Q. robur, B. pendula, $S$. caprea and $P$. tremula) have no more than three. Further, species differ in the amplitude of the growth "waves"; reactive trees (P. tremula, S. caprea, B. pendula and U. glabra), in particular, have growth "wave" amplitudes which are double those of the other species (see Fig. 2C). This evidences that reactive species are more active in responding to improved illumination.

The growth of the aerial axis can be also described by average annual height increments. This value, on the one hand, characterizes the species' rate of response to illumination in the habitat and, on the other, reflects the ability of the plants to reduce the intensity of the growth processes under unfavourable light conditions. Maximal average annual height increments at light deficit occur in $P$. tremula, $S$. caprea and B. pendula. These species are usually the first to emerge in the forest stand when a large treefall gap appears. T. cordata, C. betulus, F. excelsior, P. abies and Acer spp. are characterized by smaller annual increments (Table 6 ). For example, at stage $j$, the average height increase in $C$. betulus, $F$. excelsior, A. platanoides and $P$. abies is less than one centimetre. This demonstrates that under minimum light conditions these species are able, to a greater extent than the others, to redirect the flow of organic matter from respiration in new growth processes to supporting respiration of the existing structures.

Table 6

Average annual growth in height $\left(M \pm m_{M}, \mathrm{~cm}^{\cdot} \cdot \mathrm{ear}^{-1}\right)$ of the trees in the undergrowth under the forest canopy in minimum light at different ontogenetic stages

\begin{tabular}{|l|c|c|c|c|c|}
\hline \multirow{2}{*}{\multicolumn{1}{|c|}{ Tree species }} & \multicolumn{5}{c|}{ Ontogenetic stages } \\
\cline { 2 - 6 } & $j$ & im $_{1}$ & im $_{2}$ & $v_{1}$ & $v_{2}$ \\
\hline Populus tremula & $17.2 \pm 2.70$ & $15 \pm 1.6$ & $27 \pm 2.0$ & $28 \pm 3.0$ & $42 \pm 4.0$ \\
\hline Salix caprea & $15.8 \pm 3.59$ & $11 \pm 2.0$ & $20 \pm 1.8$ & $22 \pm 2.8$ & $38 \pm 3.0$ \\
\hline Betula pendula & $13.9 \pm 4.40$ & $14 \pm 1.6$ & $20 \pm 2.0$ & $21 \pm 2.7$ & $33 \pm 1.4$ \\
\hline Quercus robur & $6.1 \pm 0.50$ & $5 \pm 0.4$ & $14 \pm 0.8$ & $13 \pm 1.2$ & $21 \pm 0.6$ \\
\hline Pinus sylvestris & $3.0 \pm 0.22$ & $4 \pm 0.3$ & $8 \pm 1.1$ & $13 \pm 1.2$ & $15 \pm 1.0$ \\
\hline Tilia cordata & $2.0 \pm 0.20$ & $4 \pm 0.2$ & $8 \pm 0.4$ & $11 \pm 0.5$ & $20 \pm 1.2$ \\
\hline Ulmus glabra & $1.8 \pm 0.20$ & $6 \pm 0.5$ & $15 \pm 0.7$ & $19 \pm 1.4$ & $30 \pm 5.5$ \\
\hline Acer tataricum & $1.4 \pm 0.13$ & $3 \pm 0.2$ & $8 \pm 1.0$ & $6 \pm 0.5$ & - \\
\hline Acer campestre & $1.1 \pm 0.10$ & $3 \pm 0.2$ & $6 \pm 0.4$ & $8 \pm 0.5$ & $17 \pm 0.2$ \\
\hline Carpinus betulus & $0.9 \pm 0.10$ & $4 \pm 0.2$ & $9 \pm 0.5$ & $14 \pm 0.8$ & $19 \pm 1.6$ \\
\hline Fraxinus excelsior & $0.9 \pm 0.10$ & $3 \pm 0.2$ & $8 \pm 0.5$ & $11 \pm 0.5$ & $17 \pm 2.4$ \\
\hline Acer platanoides & $0.8 \pm 0.10$ & $4 \pm 0.3$ & $7 \pm 0.4$ & $8 \pm 0.4$ & $16 \pm 1.8$ \\
\hline Picea abies & $0.2 \pm 0.03$ & $1 \pm 0.1$ & $2 \pm 0.1$ & $6 \pm 0.5$ & $26 \pm 0.9$ \\
\hline
\end{tabular}

Note: $M$ - arithmetic mean, $m_{M}-$ average error. 
Status of the undergrowth trees' crowns. Light in the forest is characterized by horizontal heterogeneity. Treefall gaps, formed at the site of old trees which have fallen, are more illuminated than habitats under the closed canopy of adult trees $[55,56]$. This is reflected in the morphological fea- tures of the crown. The study describes the crowns formed in the treefall gaps and under the canopy of the forest. Let us consider undergrowth trees that have reached stage $v_{1}$ in their development, as an example.

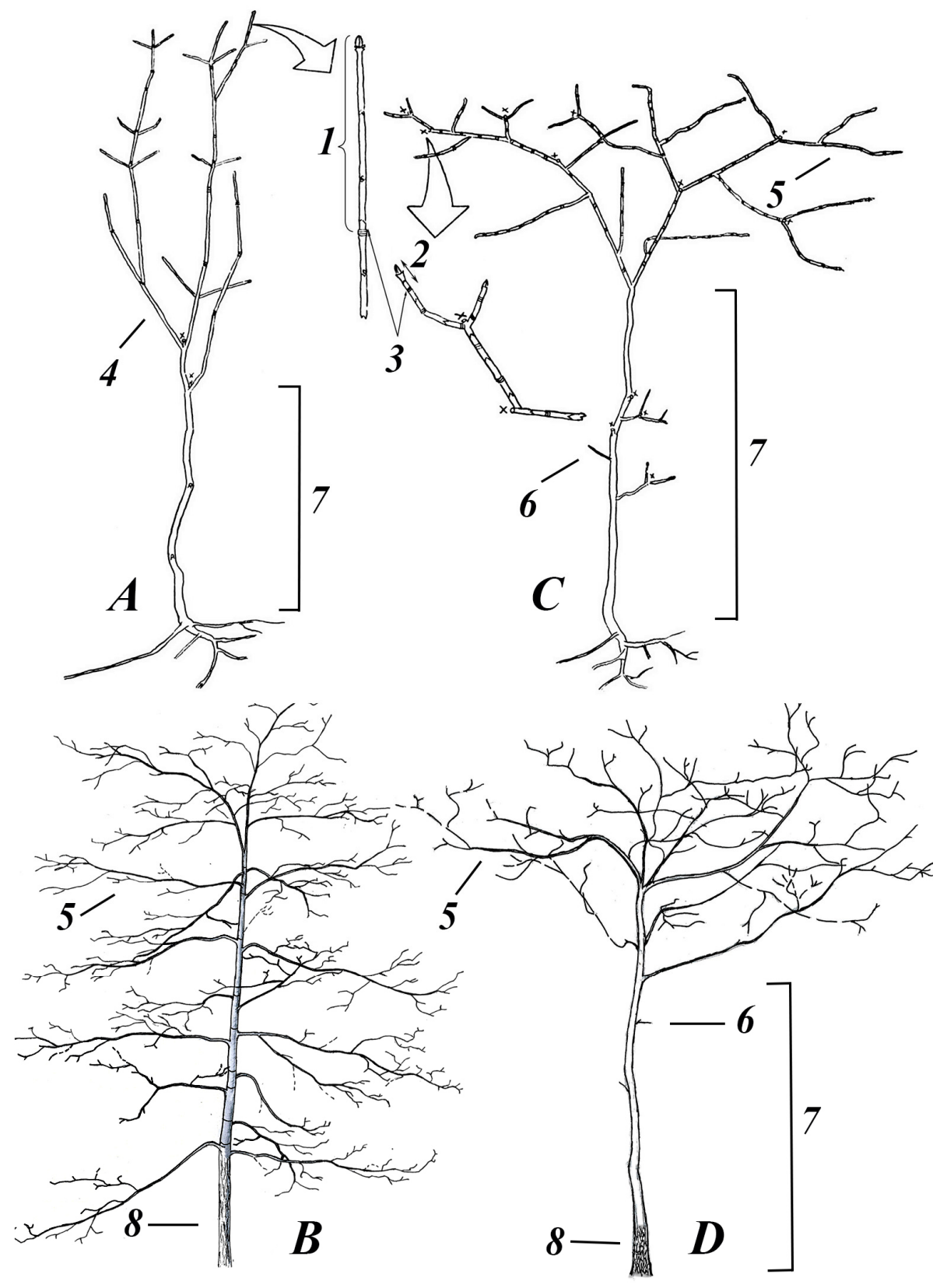

Fig. 5. The appearance of virginile undergrowth in the first subgroup $\left(v_{1}\right)$ which was formed in treefall gaps $(A, B)$ and under the forest canopy at light minimum $(C, D)$. The top row $(A, C)$ is Acer platanoides, the bottom row $(B, D)$ is Quercus robur. Undergrowth height is 5 metres. Legend: 1 - annual increment in height in treefall gap; 2 - annual increment in height in minimum light; 3 - borders of annual increment; 4 - side branches extending at an acute angle; 5 - side branches extending at a right angle (plagiotropic shoots); 6 - dead side branches; 7 - part of the trunk cleared of lower branches; 8 - fracture of the cortex at the base of the stem

In species growing in large openings the crown is extended vertically and has a cylindrical shape (Fig. 5A, 5B). In some species (for example, shadetolerant $A$. platanoides) laterals branch from the trunk at an acute angle while others develop at a right angle (for example, low shade-tolerant $Q$. robur). In all species, the leaves in the crown are arranged in several layers. The efficiency of such multilayer crowns is higher at higher light densities. The length of annual shoots in the crown can 
reach half a metre or more. Several pairs of leaves grow on the shoots. Greater openness of the branches weakens the light gradually, allowing the plant to develop a crown vertically. Formation of a multilayer crown is due to the development of a powerful leader shoot, which in time becomes a trunk which bears the crown. Thus, a multilayer crown, which is extended vertically, and large annual increments with a great number of leaves are evidence of active growth processes in undergrowth trees.

Trees growing in minimum light usually have umbrella-shaped crowns, in which the leaves are arranged in almost a single layer (Fig. 5C, 5D). The efficiency of such single-layer crowns is higher at low light densities. The plant forms long, thin, horizontally arranged shoots, with relatively wide leaves, and inter-shadowing of leaves is minimal so the scattered light and flecks of sunlight are collected from a larger area. Annual increments of recent years are minimal: for example, Acer spp. and $F$. excelsior grew no more than a centimetre, adding only one pair of leaves. A detailed study of the branches reveals many traces of shoot sympodial growth, which is not determined by heredity but by lack of the light. Thus, the umbrella-shaped crown, frequent sympodial growth of the shoot system and minimal annual increments are evidence that the plant has reduced growth processes and is waiting for an improvement in light conditions (an opening in the canopy) at a low level of vitality.

The tendency to form an umbrella-shaped crown in the species studied is variable (Table 7). Clearly expressed umbrella-shaped crowns were not found in undergrowth examples of $S$. caprea, $P$. tremula and $P$. sylvestris. This is because their regeneration is dependent upon open spaces (uncultivated arable land, burnt areas in the forest), light park forests and pine forests, as well as large treefall gaps. Under these conditions, solar energy is more efficiently captured by a crown that is extended vertically. Umbrella-shaped crowns were identified in $B$. pendula and $Q$. robur exclusively in light forests (pine and birch forests), and in A. spp., U. glabra, T. cordata, P. abies, C. betulus and $F$. excelsior in dark deciduous and coniferousdeciduous forests. At $v_{1}$ the species U. glabra and A. platanoides formed the maximal crown area. $F$. excelsior was unable to create a wide umbrellashaped crown like A. platanoides and U. glabra, which is one of the possible causes of its significant weakening of shade tolerance at stage $v_{1}$.

Table 7

Crown diameter $(m)$ of undergrowth trees at $v_{1}$ ontogenetic stage in minimum light

\begin{tabular}{|l|c|c|c|}
\hline \multirow{2}{*}{ Tree species } & \multicolumn{3}{c|}{ Crown diameter, $m$} \\
\cline { 2 - 4 } & $M \pm m_{M}$ & $\sigma$ & $N$ \\
\hline Ulmus glabra & $2.3 \pm 0.09$ & 0.33 & 15 \\
\hline Acer platanoides & $2.3 \pm 0.07$ & 0.28 & 15 \\
\hline Acer campestre & $2.0 \pm 0.10$ & 0.30 & 10 \\
\hline Tilia cordata & $1.9 \pm 0.09$ & 0.30 & 21 \\
\hline Picea abies & $1.9 \pm 0.15$ & 0.67 & 11 \\
\hline Carpinus betulus & $1.7 \pm 0.05$ & 0.17 & 14 \\
\hline Acer tataricum & $1.1 \pm 0.05$ & 0.19 & 18 \\
\hline Betula pendula & $1.1 \pm 0.03$ & 0.11 & 12 \\
\hline Pinus sylvestris & $1.1 \pm 0.10$ & 0.34 & 15 \\
\hline Fraxinus excelsior & $1.0 \pm 0.05$ & 0.19 & 10 \\
\hline Quercus robur & $0.9 \pm 0.05$ & 0.15 & \\
\hline
\end{tabular}

Note: $M$ - arithmetic mean, $m_{M}$ - average error, $\sigma$ - mean of square deviation, $N$ - sample size.

An important factor in the normalization of photosynthetic activity of the growing undergrowth is constant improvement of light conditions provided by the death and fall of old trees (see Fig. 1). Observation of different species of broad-leaved trees with umbrella-shaped crowns (at stage $v_{1}$ ) showed that on creation of an opening they activate growth and for two to three years form a large leader shoot and a multilayer crown, which is extended vertically. The ecological consequence of such reconfiguration is rapid development of free resources and rapid exit to the upper layer for further development and reproduction.
Length of life of undergrowth trees. One of the ways that tree populations survive under unfavourable cenotic conditions is by the formation of a "reserve" of young trees that check their growth at the initial stages until light conditions alter. These species have low vitality. They need minimum resources, are capable of growing under the forest canopy and act as a population pool, when cenotic conditions become better their development continues. The ability of trees to form a population pool can be assessed by the length of life of the individuals in the undergrowth under conditions of light deficiency. 
Tree species can be arranged according to the average length of life of $\mathrm{im}_{2}$ plants under deep shade conditions in the following order (from shortto long-lived species): $P$. tremula, B. pendula, S. caprea, U. glabra, Q. robur, C. betulus, $P$. sylvestris, A. tataricum, T. cordata, F. excelsior, P. abies, A. campestre, A. platanoides (Table 8). The length of life of the younger generation under light deficiency depends on the ability of the plants in the undergrowth to store the organic compounds produced by photosynthesis. This ability is inherently low in the undergrowth species mentioned at the head of the order; these plants have high respiratory capacity $[18,22,24,25,50]$ and they die rapidly with lack of light. Populations at the end of the order have a greater capacity to store organic compounds and low respiratory activity $[22,25$, $50]$ and in case of forced dormancy they can survive periods of adversity for a considerable period of time.

Table 8

Average age and age range (in brackets) of the trees in the undergrowth at different ontogenetic stages under forest canopy in minimum light

\begin{tabular}{|l|c|c|c|c|c|}
\hline \multirow{2}{*}{ Tree species } & \multicolumn{5}{|c|}{ Ontogenetic stages } \\
\cline { 2 - 6 } & $j$ & $i_{1}$ & im $_{2}$ & $v_{1}$ & $v_{2}$ \\
\hline Populus tremula & $1.5(1-2)$ & $5.3(4-7)$ & $8.7(6-11)$ & $10.3(4-16)$ & $15.2(12-18)$ \\
\hline Betula pendula & $1.7(1-2)$ & $5.5(4-7)$ & $9.1(6-12)$ & $10.4(9-12)$ & $24.7(22-28)$ \\
\hline Salix caprea & $1.9(1-3)$ & $6.0(4-8)$ & $9.1(6-13)$ & $13.7(8-20)$ & $18.0(16-20)$ \\
\hline Quercus robur & $3.9(3-5)$ & $6.8(5-9)$ & $11.8(10-14)$ & $18.0(12-24)$ & $27.5(26-29)$ \\
\hline Pinus sylvestris & $4.0(3-5)$ & $8.4(7-10)$ & $16.0(9-22)$ & $16.0(14-18)$ & $52.0(42-62)$ \\
\hline Picea abies & $4.3(3-6)$ & $8.3(5-10)$ & $19.2(14-25)$ & $40.6(34-48)$ & $67.4(59-76)$ \\
\hline Ulmus glabra & $5.5(3-8)$ & $8.6(5-12)$ & $11.5(9-14)$ & $16.3(11-22)$ & $23.0(21-25)$ \\
\hline Carpinus betulus & $5.5(4-7)$ & $15.2(11-29)$ & $15.8(13-19)$ & $18.8(16-22)$ & $28.0(24-32)$ \\
\hline Fraxinus excelsior & $6.2(5-7)$ & $13.5(10-17)$ & $19.1(15-23)$ & $23.8(20-28)$ & $31.5(26-37)$ \\
\hline Acer platanoides & $6.7(4-9)$ & $13.5(7-17)$ & $25.6(19-32)$ & $32.7(28-37)$ & $33.3(32-35)$ \\
\hline Acer tataricum & $6.8(4-9)$ & $13.5(9-18)$ & $16.7(11-22)$ & $34.9(29-41)$ & - \\
\hline Tilia cordata & $8.0(6-10)$ & $14.2(10-18)$ & $18.3(15-21)$ & $20.5(17-24)$ & $24.7(24-25)$ \\
\hline Acer campestre & $9.0(5-13)$ & $12.0(9-18)$ & $20.6(18-24)$ & $27.9(23-32)$ & $33.0(30-36)$ \\
\hline
\end{tabular}

The long-lived undergrowth species allow trees to form populations with large numbers of young plants. Studies carried out in the hornbeam forest of the Kanevsky Nature Reserve have shown that among shade tolerant species young $A$. platanoides typically occurs in greatest numbers in the undergrowth and the young $U$. glabra population is least abundant $[9,38]$. The average life span of $\mathrm{im}_{2}$ A. platanoides and $U$. glabra plants under the canopy at the minimum light level is 26 and (only) 12 years, respectively (Table 8 ).

The ability of the undergrowth to enter a quasi-senile (qs) state. The lifespan of the plants in the undergrowth under unfavourable conditions can be significantly extended if some of them enter a $q s$ state [57]. Quasi-senile individuals are plants that are able to maintain the lowest vitality level and regenerate when life circumstances become better. Foresters call this type of the undergrowth "snag" ("torchok" in Russian) [2, 58].

$\mathrm{Im}_{1}, \mathrm{im}_{2}$ and $v_{1}$ trees in the undergrowth can enter a $q s$ state: almost all of the aboveground parts of the plant die but the xylopodium and roots remain alive beneath the ground (Fig. 6, 7). The xylopodium is the underground part of the plant which is formed from its woody aerial growth and the basal part of the main or adventitious roots $[59,60]$. New immature- or virginile-like aboveground skeletal axes, which die in 10-20 years, develop from dormant buds on the xylopodium. As a result, xylopodia can be embodied by a system of several stumps (basal part of outgrowth) with adventitious roots. Stumps also have a store of dormant buds, out of which a subsequent generation of skeletal axes develops. They follow each other and in this state the plant "waits' for appropriate circumstances (the opening up of the area) for further development. In terms of absolute age, $Q$. robur and C. betulus are the first to become quasi-senile, the other species attain this stage later. After entering the $q s$ state the lifespan of $i m$ individuals increases, for instance, life expectancy rose for $Q$. robur from 14 to 29 years, for $U$. glabra from 14 to 48 years, for $F$. excelsior from 23 to 50 years, for $A$. campestre from 24 to 52 years. (Tables 8, 9). A. A. Chistiakova [2] reported that im undergrowth Fagus sylvatica growing under the forest canopy at low light levels was able to retain vitality in the $q s$ state for at least 70 years. The biological significance of the ability of plants in the undergrowth to enter the qs state is that they jettison a considerable amount of the perennial (respiring) parts of the plant and as a result the plant gets extra stores of organic compounds which are necessary to achieve a long lifespan under phytocenotic stress. 


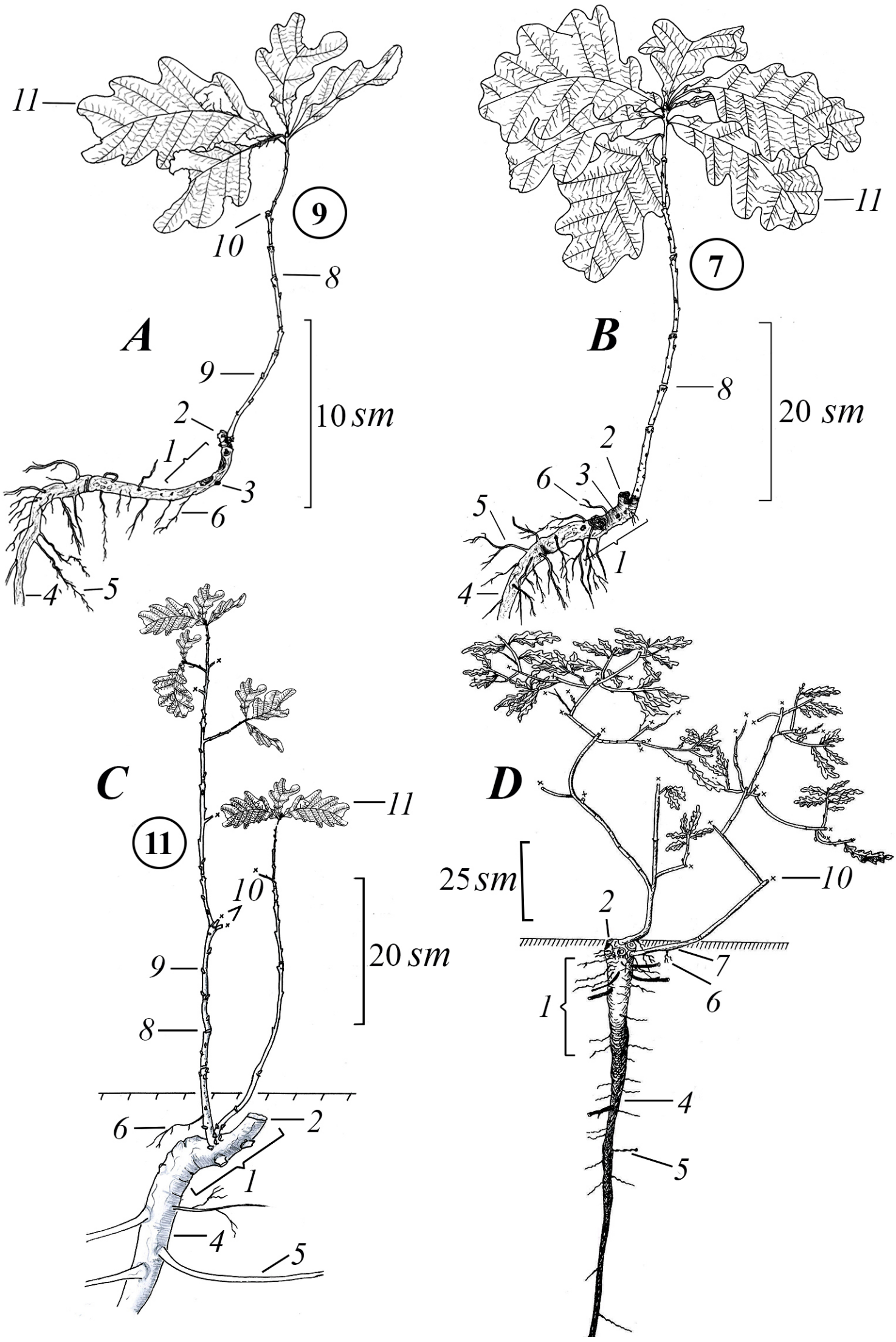

Fig. 6. Quasi-senile plants (qs) of Quercus robur: A, B - uniaxial juvenile "snags" which originated from im,

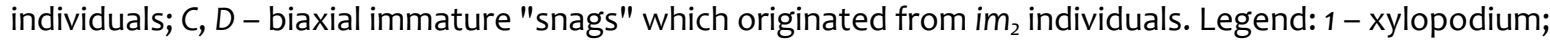

2 - "stump" or basal part of aboveground dead shoot; 3 - dormant bud on xylopodium; 4 - main root;

5 - lateral root; 6 - adventitious root; 7 - xylorhizome; 8 - border of annual growth; 9 - dormant bud on aboveground shoot; 10 - dead shoots; 11 - leaves of semi-mature (immature) type. The encircled number is the absolute age of the above-ground shoot which was formed from dormant buds in the xylopodium.

Fig. D was made by A. A. Chistyakova [56] 
Absolute age of undergrowth trees in quasi-senile (qs) state

\begin{tabular}{|l|c|c|c|c|c|}
\hline \multirow{2}{*}{\multicolumn{1}{c|}{ Tree species }} & \multicolumn{3}{c|}{ Age, years } \\
\cline { 2 - 6 } & \multirow{2}{*}{ Minimum } & \multirow{2}{*}{ Maximum } & \multicolumn{3}{c|}{ Average } \\
\cline { 2 - 6 } & & 29 & $14.7 \pm 1.00$ & 5.2 & 27 \\
\hline Quercus robur & 7 & 49 & $18.9 \pm 2.20$ & 9.7 & 20 \\
\hline Carpinus betulus & 9 & 48 & $29.9 \pm 2.30$ & 9.6 & 18 \\
\hline Ulmus glabra & 13 & 50 & $24.3 \pm 3.20$ & 12.8 & 16 \\
\hline Tilia cordata & 17 & 44 & $29.0 \pm 1.30$ & 7.5 & 34 \\
\hline Acer platanoides & 14 & 52 & $28.7 \pm 2.00$ & 9.4 & 23 \\
\hline Acer tataricum & 15 & 50 & $26.6 \pm 1.60$ & 9.1 & 33 \\
\hline Fraxinus excelsior & 12 & & & \\
\hline
\end{tabular}

Note. $M$ - arithmetic mean, $m_{M}$ - average error, $\sigma$ - mean of square deviation, $N$ - sample size. The age of the $q s$ of plants was determined by A. A. Chistyakova.

In any case, when they reach a given age, some individuals die and others enter the $q s$ state. In plants in the $q s$ state, new regeneration shoots develop from dormant buds on the xylopodium. Fig. $6(A, B, C)$ depicts individuals of $Q$. robur in the $q s$ state, where the ages of the aerial skeletal axes of the succession generations are 9, 7 and 11 years, respectively. The structure of individuals in a $q s$ state can display a number of aerial skeletal axes, which develop from dormant buds on the xylopodium. The number of axes depends on the biological age of a plant: if the individual in the $q s$ state is generated from undergrowth plants at stage $i m_{1}$, one axis shoot usually forms (see Fig. $6 A, 6 B$ ), if individuals form from individuals at stage $\mathrm{im}_{2}$ shoots have two axes (see Fig. $6 C, 6 D$ ), and multiple axes are characteristic of $v_{1}$ undergrowth (see Fig. $7 A$ ). In other words, the stronger the xylopodium, the greater number of aerial axess of regeneration it can maintain. Our findings show that $\mathrm{im}_{l}$ individuals of $Q$. robur in forced dormancy are able to live for up to 40 years, $i m_{2}$ and $v_{1}$ individuals may live up to 49 and 67 years, respectively.

Analysis of sets of data in the literature [37, 57, 61] and data from our research showed that in the tree sinusia, species can be divided into four groups according to their $q s$-formation capacity. The first group is represented by $F$. sylvatica, $A$. campestre and $A$. platanoides. Individuals of these species in the qs state are able to grow in the most shaded communities which are formed, for example, by $F$. sylvatica and $C$. betulus. Individuals of F. excelsior, U. glabra, T. cordata, Sorbus aucuparia and $C$. betulus are able to become $q s$ at higher light intensity, for instance under an oak canopy. The third group includes $Q$. robur, Malus sylvestris, A. tataricum, B. pendula, S. caprea and $P$. tremula. You can only find individuals of these species in the $q s$ state in the undergrowth of lightly shading tree communities, such as birch and pine forests, and at the edge of broadleaved and conif- erous broadleaved forests. The fourth group is made up of $P$. abies and $P$. sylvestris; these species are unable to enter the qs state, probably because of a lack of viable dormant buds in the xylopodium.

Studies of tree population dynamics in shaded forests showed that individuals in the $q s$ state account for 60 to 70 per cent of im plants of $F$. sylvatica and $A$. campestre, from 25 to 30 percent of im plants of $Q$. robur and from 3 to 20 percent of im plants of T. cordata, C. betulus, F. excelsior and U. glabra [37, 57]. The histories of $q s$ undergrowth plants vary: when the light intensity increases, some skeletal axes begin to develop actively and the plant enters the generative stage, if light conditions remain unchanged the tree may eventually die or skeletal axes, which are replaced by new ones developed from dormant buds, dry up.

Rates of undergrowth growth. Different species in the undergrowth have different rates of development under the forest canopy. Development rate is the rate at which trees grow in certain ontogenetic stages. The rate of development of plants in the undergrowth under the forest canopy is slower compared to that of plants in the open air with $100 \%$ sunlight. For instance, trees of all species in a nursery under full sunlight become $\mathrm{im}_{1}$ individuals by the end of the first season, yet under the forest canopy the development of these trees is restrained for many years at stage $j$. For instance, under minimum light intensity the $j$ stage may last for up to 13 years in $A$. campestre, up to 10 years in $T$. cordata, up to 9 years in $A$. platanoides, up to 8 years in $U$. glabra, up to 7 years in $C$. betulus and $F$. excelsior, up to 6 years in $P$. abies, up to 5 years in $Q$. robur and $P$. sylvestris, up to 3 years in $S$. caprea, and up to 2 years in $B$. pendula and $P$. tremula (Table 8). Comparison of the periods of time within which the plant lives at the same ontogenetic stage under different light conditions showed that with greater total light availability the 
transition between ontogenetic stages in the plants occurs more rapidly (see Fig. 1). For instance, stage $j$ in A. campestre may last for 13 years at $0.4 \%$ of full light but lasts for 4 years at $0.5 \%$ of full light, for 2 years at $0.6 \%$ of full light, and for less than a year at $100 \%$ light. In $T$. cordata stage $j$ may continue up to 10 years at $0.6 \%$ of full light, up to 5 years at $0.7 \%$ of full light, up to 2 years at $0.8 \%$ of total light, and for about a year at $100 \%$ of total light.
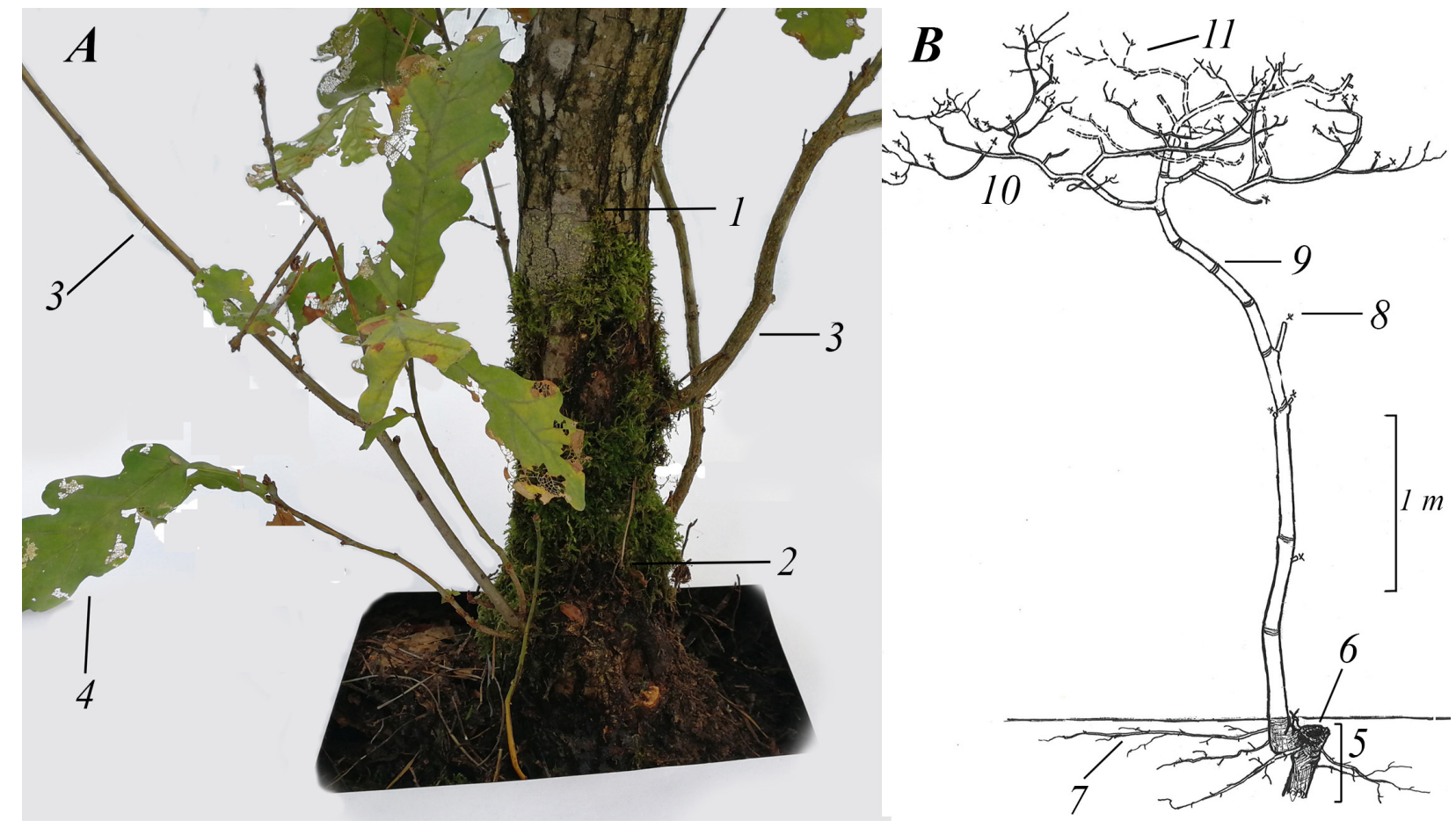

Fig. 7. Quasi-senile (qs) Quercus robur plants. A - multiaxial immature "snag" which originated from a $v_{1}$ individual; $B$ - monoaxial virginile "snag" which originated from a $v_{1}$ individual.

Legend: 1 - dead aboveground shoot of $v_{1}$ individual; 2 - basal living part of dead aboveground shoot with reserve of dormant buds (upper part of xylopodium, future "stump"); 3 - renewal shoot of immature appearance which formed from dormant buds in the xylopodium; 4 - leaves of semi-mature (immature) type; 5 - xylopodium;

6 - "stump" or basal part of dead aboveground shoot; 7 - adventitious root; 8 - dead lateral branch in lower part of trunk (showing stem cleansing); 9 - border between annual growth sections; 10 - umbrella-shaped crown with plagiotropic shoots; 11 - dead branches in umbrella-shaped crown. Crosses - dead shoots

During the development of the undergrowth under the forest canopy, transition from one ontogenetic stage to another is spasmodic and fast. This is caused by the availability of extra light because of the formation of an open area at the upper layer (see Fig. 1). For instance, when $F$. excelsior grows at $0.4 \%$ of total light under the forest canopy, it reaches only stage $j$ and lives at this stage no longer than 7 years and then dies. However, if for this period of time the amount of light increase to $0.5 \%$ of total light and the juvenile $F$. excelsior immediately enters the $i m_{l}$ stage within a year and it can then live another ten years at this stage. In general, the histories of $\mathrm{im}_{1} F$. excelsior individuals are different. Some species die when they reach their maximum age, others reduce their energy demand, discarding some of their respiring tissues and entering a lower level of vitality, the $q s$ state, in which they can live for many years. In addition, there are other individuals which enter the next ontogenetic stage $\left(\mathrm{im}_{2}\right)$ when light conditions improve. It does not take much time, one to three years, to achieve this transition, indicated by the curved arrow in Fig. 1. In fact, trees in the undergrowth that live until the formation of an appropriate open area with the required light intensity take up a space in the tree layer. Thus, in the forest community the polyvariance of undergrowth development is obvious and determined by spatialtemporal variations in light conditions

\section{Conclusion}

Having evaluated the ecological and biological properties of trees under minimum light intensity, species with different combinations of interrelated traits were divided into two different groups.

The first group includes $P$. tremula, B. pendula, $S$. caprea, $P$. sylvestris and $Q$. robur. In the undergrowth these species have low shade-tolerance in combination with rapid growth rates, high intensity of growth and physiological processes (photosyn- 
thesis and respiration), large annual average biomass growth and short lifespans at low light level. Species which have the above set of traits are able to live in light communities such as large open areas in places where a number of trees have fallen and in park-type broken forests.

The second group is represented by $A$. platanoides, A. campestre, A. tataricum, T. cordata, $U$. glabra, F. excelsior, P. abies and C. betulus. In the undergrowth these species exhibit high shade-tolerance in combination with slow growth rates, low intensity of growth and physiological processes, small annual average biomass growth and long life under conditions of light deficiency. Species which have the above set of traits are able to live under the dark forest canopy formed by $P$. abies and broadleaved trees with shading crowns.

These two different groups of species with differing development of biological and ecological properties are considered to be complementary formations of vegetation cover. They form communities in contrasting ecological conditions: open and shaded forests. The tree species in each group determine the tolerance of the forest communities since they are able to replace one another if the number of individuals of any species falls. The similar light requirements and biological properties of these species form the basis of this ability. The varying responses of trees to different light conditions in the forest result in polyvariant tree development. Hence, the undergrowth under the forest canopy exists at different ontogenetic stages and may wait for long periods of time for an increase in light abundance. The undergrowth, which stops growing because of light deficiency and lives for a long time in an unchanged stage, enters the subsequent ontogenetic stage in cases of accretion thinning and increased light intensity and gradually occupies the upper layer. Moreover, polyvariance of ontogeny leads to optimal use of available environmental resources by the undergrowth. At the same time, because of the disturbance of natural forest mosaics as a result of large-scale deforestation the diverse paths of the trees' ontogeny are not implemented in most cenoses. This is a key factor in understanding why forest degradation increasingly occurs.

\section{Библиографический сnисок}

1. Алексеев, В. А. Световой режим леса / В. А. Алексеев. - Ленинград : Наука, 1975. - 228 с.

2. Диагнозы и ключи возрастных состояний лесных растений. Деревья и кустарники : метод. разработки для студ. биол. специальностей / А. А. Чистякова, Л. Б. Зауголькова, И. В. Полтинкина, И. С. Кутьина, Н. Н. Лащинский. - Москва : Прометей, 1989. - 102 с.

3. Ontogeny of a tree / O. V. Smirnova, A. A. Chistyakova, L. B. Zaugolnova, O. I. Evstigneev, R. V. Popadiouk, A. M. Romanovsky // Ботанический журнал. - 1999. - Т. 84 (12). - C. 8-19.

4. Заугольнова, Л. Б. Ценопопуляции растений (очерки популяционной биологии) / Л. Б. Заугольнова, Л. А. Жукова, А. С. Комаров, О. В. Смирнова. - Москва : Наука, 1988. - 184 с.

5. Сабинин, Д. А. Физиология развития растений / Д. А. Сабинин. - Москва : Изд-во АН СССР, 1963. - 196 с.

6. Жукова, Л. А. Популяционная жизнь луговых растений / Л. А. Жукова. - Йошкар-Ола : РИИК «Ланар», 1995. $-224 \mathrm{c}$.

7. Евстигнеев, О. И. Механизмы поддержания биологического разнообразия лесных биогеоценозов : дис. ... д-ра биол. наук / Евстигнеев О. И. - Н. Новгород : НГУ им. Н. И. Лобачевского, 2010. - 513 с.

8. Растительность Европейской части СССР / под ред. С. А. Грибовой, Т. И. Исаченко, Е. М. Лавренко. - Ленинград : Наука, 1980. - 431 с.

9. Евстигнеев, О. И. Популяционная организация грабовых лесов Каневского заповедника / О. И. Евстигнеев, В. Н. Коротков, Л. В. Бакалына // Бюллетень Московского общества испытателей природы. Отдел биологический. - 1992. - Т. 97 (2). - С. 81-89.

10. Карманова, И. В. О конкурентном воздействии надземных и подземных частей древостоя на рост подроста / И. В. Карманова // Экспериментальное изучение биогеоценозов тайги : сб. ст. / отв. ред. В. Н. Сукачев, В. Г. Карпов. - Ленинград : Наука, 1969. - С. 68-79.

11. Карпов, В. Г. Экспериментальная фитоценология темнохвойной тайги / В. Г. Карпов. - Ленинград : Наука, 1969. - $335 \mathrm{c}$.

12. Мишнев, В. Г. Биологические основы воспроизводства буковых лесов Крыма : автореф. дис. ... канд. биол. наук / Мишнев В. Г. - Минск, 1973. - 50 с.

13. Евстигнеев, О. И. Поливариантность сосны обыкновенной в Брянском полесье / О. И. Евстигнеев // Лесоведение. - 2014. - № 2. - С. 69-77.

14. Evstigneev, O. I. Ontogenetic stages of trees: an overview / O. I. Evstigneev, V. N. Korotkov // Russian Journal of Ecosystem Ecology. - 2016. - Vol. 1 (2). - P. 1-31. - DOI 10.21685/2500-0578-2016-2-1.

15. Evstigneev, O. I. Ontogenetic scales of relation of trees to light (on the example of eastern european forests) / O. I. Evstigneev // Russian Journal of Ecosystem Ecology. - 2018. - Vol. 3 (3). - P. 1-18. - DOI 10.21685/250005782018-3-3.

16. Цыганов, Д. Н. Фитоиндикация экологических режимов в подзоне хвойно-широколиственных лесов / Д. Н. Цыганов. - Москва : Наука, 1983. - 198 с. 
17. Карманова, И. В. Математические методы изучения роста и продуктивности растений / И. В. Карманова. Москва : Наука, 1976. - 223 с.

18. Цельникер, Ю. Л. Физиологические основы теневыносливости древесных растений / Ю. Л. Цельникер. Москва : Наука, 1978. - 212 с.

19. Цельникер, Ю. Л. Упрощенный метод определения поверхности хвои сосны и ели / Ю. Л. Цельникер // Лесоведение. - 1982. - № 4. - С. 85-88.

20. Боровиков, В. П. Популярное введение в программу Statistica / В. П. Боровиков. - Москва : КомпьютерПресс, 1998. - 256 c.

21. Евстигнеев, О. И. Особенности развития широколиственных деревьев под пологом леса при различной освещенности / О. И. Евстигнеев // Ботанический журнал. - 1988. - Т. 73 (12). - С. 1730-1736.

22. Малкина, И. С. Фотосинтез и дыхание подроста (методические подходы к изучению баланса органического вещества) / И. С. Малкина, Ю. Л. Цельникер, А. И. Якшина. - Москва : Наука, 1970. - 184 с.

23. Князева, И. Ф. Определение баланса органического вещества у саженцев клена остролистного в условиях разного затенения / И. Ф. Князева, И. С. Малкина, А. М. Якшина // Лесоведение. - 1971. - № 2. - С. $15-22$.

24. Якшина, А. М. Об интенсивности дыхания корневой системы клена при разном затенении / А. М. Якшина // Физиология растений. - 1978. - Т. 25 (1). - С. 64-69.

25. Лир, Х. Физиология древесных растений / Х. Лир, Г. Польстер, Г.-И. Фидлер. - Москва : Лесн. пром-сть, 1974. $-424 \mathrm{c}$.

26. Крамер, П. Физиология древесных растений / П. Крамер, Т. Козловский. - Москва : Гослесбумиздат, 1963. $627 \mathrm{c}$.

27. Евстигнеев, О. И. Отношение лиственных деревьев к свету / О. И. Евстигнеев // Биологические науки. 1991. - № 8. - С. 20-29.

28. Евстигнеев, О. И. Отношение лиственных деревьев к свету и водообеспеченности в связи со структурой леса / О. И. Евстигнеев // Лесоведение. - 1996. - № 6. - С. 26-35.

29. Смирнова, О. В. Популяционные методы определения минимальной площади лесного ценоза / О. В. Смирнова, Р. В. Попадюк, А. А. Чистякова // Ботанический журнал. - 1988. - Т. 73 (10). - С. 1423-1434.

30. Евстигнеев, О. И. Популяционная экология пионерных видов широколиственного леса / О. И. Евстигнеев, В. Н. Коротков // Бюллетень Московского общества испытателей природы. Отдел биологический. - $1992 .-$ Т. 97 (6). - С. 88-96.

31. Восточноевропейские широколиственные леса / под ред. О. В. Смирновой. - Москва : Наука, 1994. - 364 с.

32. Восточноевропейские леса: история в голоцене и современность / под ред. О. В. Смирновой. - Москва : Наука, 2004. - Кн. 2. - 575 с.

33. Никольский, В. Влияние затенения на рост однолетней сосны и ели / В. Никольский // Известия Петровской земледельческой и лесной Академии. - 1881. - Вып. 3. - С. 1-7.

34. Сураж, У. Об отношении древесных и кустарниковых пород к интенсивности освещения / У. Сураж // Лесной журнал. - 1891. - Вып. 2. - С. 196-213.

35. Турский, М. К. Лесоводство / М. К. Турский. - Москва : Сельхозгиз, 1954. - 352 с.

36. Погребняк, П. С. Общее лесоводство / П. С. Погребняк. - Москва : Колос, 1968. - 440 с.

37. Смирнова, О. В. Популяционная организация буковых лесов Закарпатья / О. В. Смирнова, А. А. Чистякова, С. И. Рипа, Н. И. Лысых // Бюллетень Московского общества испытателей природы. Отдел биологический. 1989. - Т. 94 (5). - С. 78-91.

38. Популяционная диагностика и прогнозы развития заповедных лесных массивов (на примере Каневского заповедника) / О. В. Смирнова, Р. Р. Возняк, О. И. Евстигнеев, В. Н. Коротков, Н. Я. Носач, Р. В. Попадюк, В. К. Самойленко, Н. А. Торопова // Ботанический журнал. - 1991. - Т. 76 (6). - С. 860-871.

39. Wiessner, I. Der Lichtgenuss der Pflanzen / I. Wiessner. - Leipzig, 1907. - 205 p.

40. Ткаченко, М. Е. Общее лесоводство / М. Е. Ткаченко. - Москва : Гослесбумиздат, 1952. - 600 с.

41. Евстигнеев, О. И. Влияние деятельности бобра на динамику растительности малых рек (на примере заповедника «Брянский лес») / О. И. Евстигнеев, К. В. Беляков // Бюллетень Московского общества испытателей природы. Отдел биологический. - 1997. - Т. 102 (6). - С. 34-41.

42. Евстигнеев, О. И. Ельники высокотравные - климаксные сообщества на низинных болотах Брянского полесья / О. И. Евстигнеев, М. В. Горнова // Russian Journal of Ecosystem Ecology. - 2017. - Vol. 2 (3). C. 1-23. - DOI 10.21685/2500-0578-2017-3-3.

43. Высокотравные таежные леса восточной части Европейской России / Л. Б. Заугольнова, О. В. Смирнова, Т. Ю. Браславская, С. В. Дегтева, Т. С. Проказина, Д. Л. Луговая // Растительность России. - 2009. - № 15. C. 3-26.

44. Евстигнеев, О. И. Фитоценотипы и отношение лиственных деревьев к свету : автореф. дис. ... канд. биол. наук / Евстигнеев О. И. - Москва : МГПИ им. В. И. Ленина, 1990. - 17 с.

45. Тооминг, Х. Г. Солнечная радиация и формирование урожая / Х. Г. Тооминг. - Ленинград : Гидрометеоиздат, 1977. - $200 \mathrm{c.}$

46. Тооминг, Х. Г. Экологические принципы максимальной продуктивности посевов / Х. Г. Тооминг. - Ленинград : Гидрометеоиздат, 1984. - 264 с.

47. Ремизов, Н. П. Лесное почвоведение / Н. П. Ремизов, П. С. Погребняк. - Москва : Лесн. пром-сть, 1965. $324 \mathrm{c}$. 
48. Чумакова, А. В. Ясень / А. В. Чумакова, Н. Г. Васильев. - Москва : Лесн. пром-сть, 1984. - 101 с.

49. Grime, J. P. Shade tolerance in flowering plants / J. P. Grime // Nature. - 1965. - Vol. 208 (5006). - P. 161-163.

50. Якшина, А. М. О дыхании корневых систем у различно затененных саженцев ясеня пушистого и березы повислой / А. М. Якшина // Лесоведение. - 1979. - № 2. - С. 56-61.

51. Aston, T. J. Teaching light compensation point: a new practical approach / T. J. Aston, G. Robinson // Journal of Biological Education. - 1986. - Vol. 20 (30). - P. 189-194.

52. Малкина, И. С. Влияние освещенности на световые кривые фотосинтеза березы и клена / И. С. Малкина // Лесоведение. - 1977. - № 3. - С. 21-25.

53. Wallace, L. L. Comparative physiology of successional forest trees / L. L. Wallace // Forest Hydrol. and Ecol. Coweeta. - New York, 1988. - P. 181-189.

54. Коротков, В. Н. Демутационные процессы в островных лесных массивах (на примере ГИЗЛ «Горки Ленинские» и Каневского заповедника) : автореф. дис. ... канд. биол. наук / Коротков В. Н. - Москва : МГПИ им. В. И. Ленина, 1992. - 16 с.

55. Коротков, В. Н. Новая парадигма в лесной экологии / В. Н. Коротков // Биологические науки. - 1991. № 8. - C. 7-20.

56. Коротков, В. Н. Опыты по ускорению демутационных смен в грабовых лесах Каневского заповедника / В. Н. Коротков // Бюллетень Московского общества испытателей природы. Отдел биологический. - 1990. T. 95 (2). - C. 131-141.

57. Смирнова, О. В. Квазисенильность как одно из проявлений фитоценотической толерантности растений / О. В. Смирнова, А. А. Чистякова, И. И. Истомина // Журнал общей биологии. - 1984. - Т. 45 (2). - С. $216-225$.

58. Чистякова, А. А. Большой жизненный цикл Tilia cordata Mill. / А. А. Чистякова // Бюллетень Московского общества испытателей природы. Отдел биологический. - 1979. - Т. 84 (1). - С. 85-98.

59. Шафранова, Л. М. Морфогенез и жизненная форма лапчатки мелколистной (Potentilla parvifolia Fisch.) в связи с переходом от кустарников к травам у лапчаток (Potentilla L. s. 1.) / Л. М. Шафранова // Онтогенез и возрастной состав популяций цветковых растений. - Москва : Наука, 1967. - С. 35-51.

60. Чистякова, А. А. Жизненные формы и их спектры как показатель состояния вида в ценозе (на примере широколиственных деревьев) / А. А. Чистякова // Бюллетень Московского общества испытателей природы. Отдел биологический. - 1988. - Т. 93 (6). - С. 93-105.

61. Евстигнеев, О. И. Популяционные стратегии видов деревьев // Восточноевропейские леса: история в голоцене и современность / О. И. Евстигнеев. - Москва : Наука, 2004. - Кн. 1. - С. 176-205.

\section{References}

1. Alekseev V. A. Svetovoy rezhim lesa [Forest light status]. Leningrad: Nauka, 1975, 228 p. [In Russian]

2. Chistyakova A. A., Zaugol'kova L. B., Poltinkina I. V., Kut'ina I. S., Lashchinskiy N. N. Diagnozy $i$ klyuchi vozrastnykh sostoyaniy lesnykh rasteniy. Derev'ya i kustarniki : metod. razrabotki dlya stud. biol. spetsial'nostey [Diagnoses and keys of age conditions of forest plants. Trees and bushes: method of development for students of biology]. Moscow: Prometey, 1989, 102 p. [In Russian]

3. Smirnova O. V., Chistyakova A. A., Zaugolnova L. B., Evstigneev O. I., Popadiouk R. V., Romanovsky A. M. Botanicheskiy zhurnal [Botanical journal]. 1999, vol. 84 (12), pp. 8-19. [In Russian]

4. Zaugol'nova L. B., Zhukova L. A., Komarov A. S., Smirnova O. V. Tsenopopulyatsii rasteniy (ocherki populyatsionnoy biologii) [Cenopopulations of plants (reports on populational biology]. Moscow: Nauka, 1988, 184 p. [In Russian]

5. Sabinin D. A. Fiziologiya razvitiya rasteniy [Physiology of plant development]. Moscow: Izd-vo AN SSSR, 1963, 196 p. [In Russian]

6. Zhukova L. A. Populyatsionnaya zhizn' lugovykh rasteniy [Populational life of meadow plants]. Yoshkar-Ola: RIIK «Lanar», 1995, 224 p. [In Russian]

7. Evstigneev O. I. Mekhanizmy podderzhaniya biologicheskogo raznoobraziya lesnykh biogeotsenozov: dis. d-ra biol. nauk [Mechanisms of maintaining biological diversity of forest biogeocenoses: thesis of doctor of biological sciences]. Nizhny Novgorod: NGU im. N. I. Lobachevskogo, 2010, 513 p. [In Russian]

8. Rastitel'nost' Evropeyskoy chasti SSSR [Vegetation of the USSR European part]. Eds. S. A. Gribova, T. I. Isachenko, E. M. Lavrenko. Leningrad: Nauka, 1980, 431 p. [In Russian]

9. Evstigneev O. I., Korotkov V. N., Bakalyna L. V. Byulleten' Moskovskogo obshchestva ispytateley prirody. Otdel biologicheskiy [Bulletin of Moscow Society of Naturalists. Biological Series]. 1992, vol. 97 (2), pp. 81-89. [In Russian]

10. Karmanova I. V. Eksperimental'noe izuchenie biogeotsenozov taygi: sb. st. [Experimental studies of taiga biogeocenoses: collection of articles]. Leningrad: Nauka, 1969, pp. 68-79. [In Russian]

11. Karpov V. G. Eksperimental'naya fitotsenologiya temnokhvoynoy taygi [Experimental phytocenology of dark needled taiga]. Leningrad: Nauka, 1969, 335 p. [In Russian]

12. Mishnev V. G. Biologicheskie osnovy vosproizvodstva bukovykh lesov Kryma: avtoref. dis. kand. biol. nauk [Biological basis of the Crimean beech forest reproduction: abstract of thesis of cand. of boil. sciences]. Minsk, 1973, 50 p. [In Russian]

13. Evstigneev O. I. Lesovedenie [Forest studies]. 2014, no. 2, pp. 69-77. [In Russian] 
14. Evstigneev O. I., Korotkov V. N. Russian Journal of Ecosystem Ecology. 2016, vol. 1 (2), pp. 1-31. DOI 10.21685/2500-0578-2016-2-1.

15. Evstigneev O. I. Russian Journal of Ecosystem Ecology. 2018, vol. 3 (3), pp. 1-18. DOI 10.21685/250005782018-3-3.

16. Tsyganov D. N. Fitoindikatsiya ekologicheskikh rezhimov v podzone khvoyno-shirokolistvennykh lesov [Phytoindication of ecological regimes in the subzone of spruce and broad-leaved forests]. Moscow: Nauka, 1983,198 p. [In Russian]

17. Karmanova I. V. Matematicheskie metody izucheniya rosta i produktivnosti rasteniy [Mathematical methods of studying plant growth and reproduction]. Moscow: Nauka, 1976, 223 p. [In Russian]

18. Tsel'niker Yu. L. Fiziologicheskie osnovy tenevynoslivosti drevesnykh rasteniy [Physiological basis of woody plants shade endurance]. Moscow: Nauka, 1978, 212 p. [In Russian]

19. Tsel'niker Yu. L. Lesovedenie [Forest studies]. 1982, no. 4, pp. 85-88. [In Russian]

20. Borovikov V. P. Populyarnoe vvedenie v programmu Statistica [Popular introduction into the programme of Statistics]. Moscow: Komp'yuterPress, 1998, 256 p. [In Russian]

21. Evstigneev O. I. Botanicheskiy zhurnal [Botanical journal]. 1988, vol. 73 (12), pp. 1730-1736. [In Russian]

22. Malkina I. S., Tsel'niker Yu. L., Yakshina A. I. Fotosintez i dykhanie podrosta (metodicheskie podkhody $k$ izucheniyu balansa organicheskogo veshchestva) [Phytosynthesis and breathing of undergrowth (methodological approaches to studying the balance of organic substance]. Moscow: Nauka, 1970, 184 p. [In Russian]

23. Knyazeva I. F., Malkina I. S., Yakshina A. M. Lesovedenie [Forest studies]. 1971, no. 2, pp. 15-22. [In Russian]

24. Yakshina A. M. Fiziologiya rasteniy [Plant physiology]. 1978, vol. 25 (1), pp. 64-69. [In Russian]

25. Lir Kh., Pol'ster G., Fidler G.-I. Fiziologiya drevesnykh rasteniy [Woody plants physiology]. Moscow: Lesn. prom-st', 1974, 424 p. [In Russian]

26. Kramer P., Kozlovskiy T. Fiziologiya drevesnykh rasteniy [Woody plants physiology]. Moscow: Goslesbumizdat, 1963, 627 p. [In Russian]

27. Evstigneev O. I. Biologicheskie nauki [Biological sciences]. 1991, no. 8, pp. 20-29. [In Russian]

28. Evstigneev O. I. Lesovedenie [Forest studies ]. 1996, no. 6, pp. 26-35. [In Russian]

29. Smirnova O. V., Popadyuk R. V., Chistyakova A. A. Botanicheskiy zhurnal [Botanical journal]. 1988, vol. 73 (10), pp. 1423-1434. [In Russian]

30. Evstigneev O. I., Korotkov V. N. Byulleten' Moskovskogo obshchestva ispytateley prirody. Otdel biologicheskiy [Bulletin of Moscow Society of Naturalists. Biological Series]. 1992, vol. 97 (6), pp. 88-96. [In Russian]

31. Vostochnoevropeyskie shirokolistvennye lesa [East-European broad-leaved forests]. Ed. by O. V. Smirnova. Moscow: Nauka, 1994, 364 p. [In Russian]

32. Vostochnoevropeyskie lesa: istoriya $v$ golotsene i sovremennost' [East-European forest: history in the Holocene and modern times]. Ed. by O. V. Smirnova. Moscow: Nauka, 2004, bk. 2, 575 p. [In Russian]

33. Nikol'skiy V. Izvestiya Petrovskoy zemledel'cheskoy i lesnoy Akademii [Proceedings of Peter's Academy of Agriculture and Forestry]. 1881, iss. 3, pp. 1-7. [In Russian]

34. Surazh U. Lesnoy zhurnal [Forest journal]. 1891, iss. 2, pp. 196-213. [In Russian]

35. Turskiy M. K. Lesovodstvo [Forestry]. Moscow: Sel'khozgiz, 1954, 352 p. [In Russian]

36. Pogrebnyak P. S. Obshchee lesovodstvo [General forestry]. Moscow: Kolos, 1968, 440 p. [In Russian]

37. Smirnova O. V., Chistyakova A. A., Ripa S. I., Lysykh N. I. Byulleten' Moskovskogo obshchestva ispytateley prirody. Otdel biologicheskiy [Bulletin of Moscow Society of Naturalists. Biological Series]. 1989, vol. 94 (5), pp. 78-91. [In Russian]

38. Smirnova O. V., Voznyak R. R., Evstigneev O. I., Korotkov V. N., Nosach N. Ya., Popadyuk R. V., Samoylenko V. K., Toropova N. A. Botanicheskiy zhurnal [Botanical journal]. 1991, vol. 76 (6), pp. 860-871. [In Russian]

39. Wiessner I. Der Lichtgenuss der Pflanzen. Leipzig, 1907, 205 p.

40. Tkachenko M. E. Obshchee lesovodstvo [General forest science]. Moscow: Goslesbumizdat, 1952 , 600 p. [In Russian]

41. Evstigneev O. I., Belyakov K. V. Byulleten' Moskovskogo obshchestva ispytateley prirody. Otdel biologicheskiy [Bulletin of Moscow Society of Naturalists. Biological Series]. 1997, vol. 102 (6), pp. 34-41. [In Russian]

42. Evstigneev O. I., Gornova M. V. Russian Journal of Ecosystem Ecology. 2017, vol. 2 (3), pp. 1-23. DOI 10.21685/2500-0578-2017-3-3.

43. Zaugol'nova L. B., Smirnova O. V., Braslavskaya T. Yu., Degteva S. V., Prokazina T. S., Lugovaya D. L. Rastitel'nost' Rossii [Vegetation of Russia]. 2009, no. 15, pp. 3-26. [In Russian]

44. Evstigneev O. I. Fitotsenotipy $i$ otnoshenie listvennykh derev'ev $k$ svetu: avtoref. dis. kand. biol. nauk [Phytocenotypes and relation of leaved trees to light: abstract of cand. of boil. sciences]. Moscow: MGPI im. V. I. Lenina, 1990, 17 p. [In Russian]

45. Tooming Kh. G. Solnechnaya radiatsiya i formirovanie urozhaya [Solar radiation and harvest formation]. Leningrad: Gidrometeoizdat, 1977, 200 p. [In Russian]

46. Tooming Kh. G. Ekologicheskie printsipy maksimal'noy produktivnosti posevov [Ecological principles of maximum crops productivity]. Leningrad: Gidrometeoizdat, 1984, 264 p. [In Russian]

47. Remizov N. P., Pogrebnyak P. S. Lesnoe pochvovedenie [Forest soil studies]. Moscow: Lesn. prom-st', 1965, 324 p. [In Russian]

48. Chumakova A. V., Vasil'ev N. G. Yasen' [Ash-tree]. Moscow: Lesn. prom-st', 1984, 101 p. [In Russian] 
49. Grime J. P. Nature. 1965, vol. 208 (5006), pp. 161-163.

50. Yakshina A. M. Lesovedenie [Forest studies]. 1979, no. 2, pp. 56-61. [In Russian]

51. Aston T. J., Robinson G. Journal of Biological Education. 1986, vol. 20 (30), pp. 189-194.

52. Malkina I. S. Lesovedenie [Forest studies]. 1977, no. 3, pp. 21-25. [In Russian]

53. Wallace L. L. Forest Hydrol. and Ecol. Coweeta. New York, 1988, pp. 181-189.

54. Korotkov V. N. Demutatsionnye protsessy v ostrovnykh lesnykh massivakh (na primere GIZL «Gorki Leninskie» $i$ Kanevskogo zapovednika): avtoref. dis. kand. biol. nauk [Demutational processes in insular forestlands (on the example of Nature Reserve "Gorki Leninskie" and Kanev Reserve]. Moscow: MGPI im. V. I. Lenina, 1992,16 p. [In Russian]

55. Korotkov V. N. Biologicheskie nauki [Biological sciences]. 1991, no. 8, pp. 7-20. [In Russian]

56. Korotkov V. N. Byulleten' Moskovskogo obshchestva ispytateley prirody. Otdel biologicheskiy [Bulletin of Moscow Society of Naturalists. Biological Series]. 1990, vol. 95 (2), pp. 131-141. [In Russian]

57. Smirnova O. V., Chistyakova A. A., Istomina I. I. Zhurnal obshchey biologii [General biology journal]. 1984, vol. 45 (2), pp. 216-225. [In Russian]

58. Chistyakova A. A. Byulleten' Moskovskogo obshchestva ispytateley prirody. Otdel biologicheskiy [Bulletin of Moscow Society of Naturalists. Biological Series]. 1979, vol. 84 (1), pp. 85-98. [In Russian]

59. Shafranova L. M. Ontogenez i vozrastnoy sostav populyatsiy tsvetkovykh rasteniy [Ontogenesis and age composition of flowering plants population]. Moscow: Nauka, 1967, pp. 35-51. [In Russian]

60. Chistyakova A. A. Byulleten' Moskovskogo obshchestva ispytateley prirody. Otdel biologicheskiy [Bulletin of Moscow Society of Naturalists. Biological Series]. 1988, vol. 93 (6), pp. 93-105. [In Russian]

61. Evstigneev O. I. Vostochnoevropeyskie lesa: istoriya v golotsene i sovremennost' [East-European forest: history in the Holocene and modern times]. Moscow: Nauka, 2004, bk. 1, pp. 176-205. [In Russian] 